\title{
Serotonergic Suppression of Mouse Prefrontal Circuits Implicated in Task Attention
}

\author{
(D) Michael K. Tian, ${ }^{1}$ (i) Eric F. Schmidt, ${ }^{2}$ and ${ }^{(D)}$ Evelyn K. Lambe ${ }^{1,3,4}$
}

\section{DOI:http://dx.doi.org/10.1523/ENEURO.0269-16.2016}

${ }^{1}$ Department of Physiology, University of Toronto, Toronto, ON, Canada, ${ }^{2}$ Laboratory of Molecular Biology, Rockefeller University, New York, NY, ${ }^{3}$ Department of Obstetrics and Gynecology, University of Toronto, Toronto, ON, Canada, and ${ }^{4}$ Department of Psychiatry, University of Toronto, Toronto, ON, Canada

\section{Visual Abstract}

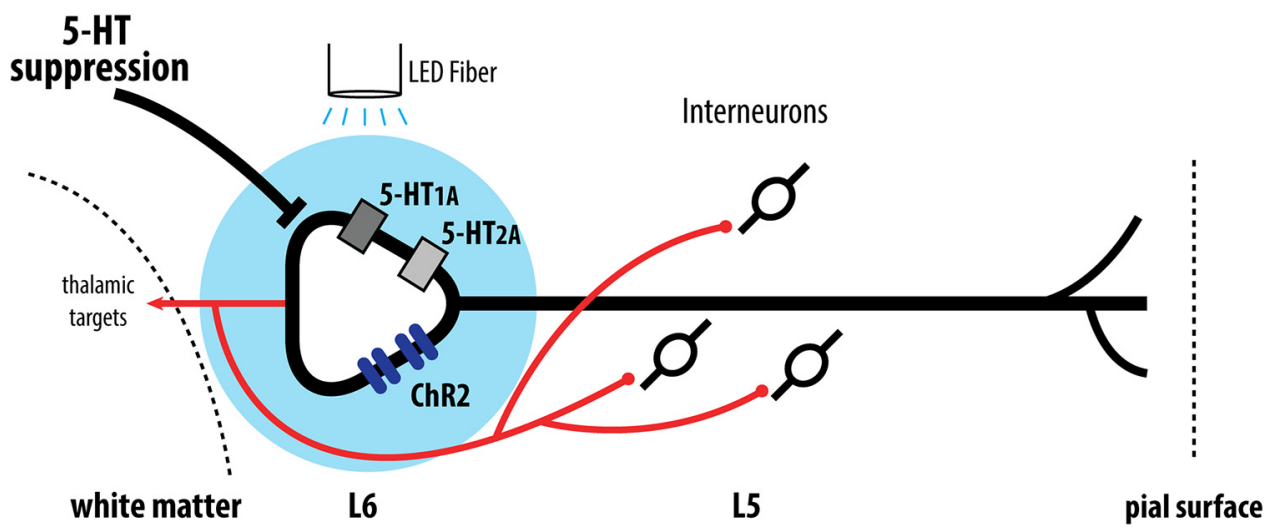

Serotonin (5-HT) regulates attention by neurobiological mechanisms that are not well understood. Layer 6 (L6) pyramidal neurons of prefrontal cortex play an important role in attention and express 5-HT receptors, but the serotonergic modulation of this layer and its excitatory output is not known. Here, we performed whole-cell recordings and pharmacological manipulations in acute brain slices from wild-type and transgenic mice expressing either eGFP or eGFP-channelrhodopsin in prefrontal L6 pyramidal neurons. Excitatory circuits between L6 pyramidal neurons and L5 GABAergic interneurons, including a population of interneurons essential for task attention, were investigated using optogenetic techniques. Our experiments show that prefrontal L6 pyramidal neurons are subject to strong serotonergic inhibition and demonstrate direct 5-HT-sensitive connections between prefrontal L6 pyramidal neurons and two classes of L5 interneurons. This work helps to build a neurobiological framework to appreciate serotonergic disruption of task attention and yields insight into the disruptions of attention observed in psychiatric disorders with altered 5-HT receptors and signaling.

Key words: corticothalamic neurons; interneurons; medial prefrontal cortex; optogenetics; serotonin (5-HT)

\section{Significance Statement}

Although serotonin shapes and biases attention, the mechanisms underlying this phenomenon are not well understood. Layer 6 (L6) pyramidal neurons of medial prefrontal cortex play a critical role in performance on attention tasks, but their serotonergic modulation is unclear. Using electrophysiology and optogenetic techniques, we investigated the effects of serotonin on L6 pyramidal neurons and their local cortical circuits. We discovered a direct and serotonin-sensitive functional link from prefrontal L6 pyramidal neurons to GABAergic interneurons in L5, two populations of neurons essential for attention. 


\section{Introduction}

The medial prefrontal cortex (mPFC) is critical for "topdown" executive control of attention (Miller and Cohen, 2001; Knudsen, 2007), and disruption of its signaling impairs normal performance on attention tasks (Muir et al., 1996; Miner et al., 1997; Granon et al., 1998). Layer 6 (L6) of mPFC, in particular, plays an important role in attention (Alitto and Usrey, 2003; West et al., 2006; Zikopoulos and Barbas, 2006; Kassam et al., 2008; Bailey et al., 2010; Guillem et al., 2011) and is a major source of corticothalamic output (Guillery and Sherman, 2002; Thomson et al., 2002; Mercer et al., 2005; Watts and Thomson, 2005; West et al., 2006; Zikopoulos and Barbas, 2006; Parikh et al., 2007; Sherman, 2007; Kassam et al., 2008; Bailey et al., 2010; Thomson, 2010). Much less, however, is known about the cortico-cortical collaterals of L6 pyramidal neurons in MPFC. This question is increasingly urgent in view of recent work from primary sensory cortex showing that L6 pyramidal neurons send robust excitatory projections to fast-spiking cortical interneurons which achieve strong gain control over the cortical column (Olsen et al., 2012), together with recent work from mPFC showing that fast-spiking prefrontal interneurons are essential for attention (Kim et al., 2016). In $\mathrm{mPFC}$, there remains much to be understood about the local targets of prefrontal L6 pyramidal neurons and the susceptibility of these attention circuits to neuromodulators such as serotonin.

Serotonin (5-HT) is known to shape and bias attention in human and nonhuman primates, with reduction of brain 5-HT enhancing attention (Schmitt et al., 2000; Gallagher et al., 2003; Booij et al., 2005; Wingen et al., 2007) and elevation of brain 5-HT impairing attention task performance (Riedel et al., 2005; Oranje et al., 2008; Watson et al., 2015). Yet the mechanisms underlying this relationship between 5-HT and attention are not well understood. As in primates, the deep layers of mPFC in rodents are well innervated by serotonin afferents (Wilson and Mol-

Received August 29, 2016; accepted October 21, 2016; First published October 27, 2016.

Authors report no conflict of interest.

Author contributions: MKT, EFS, and EKL designed research; MKT and EFS performed research and analyzed data; MKT, EFS, and EKL wrote the paper.

This work was supported by a Discovery Grant from the Natural Sciences and Engineering Research Council of Canada, the Canada Research Chair in Developmental Cortical Physiology, an Early Researcher Award from the Province of Ontario, and the Canadian Foundation for Innovation (EKL); a Banting and Best Canada Graduate Scholarship from CIHR (MKT); a Brain and Behavior Research Foundation NARSAD Young Investigator Grant; the van Ameringen Foundation (EFS), and Canada Research Chairs (Chaires de recherche du Canada (EKL)).

Acknowledgments: We thank Dr. Nathaniel Heintz of the Rockefeller University for the gift of Epiphycan-Cre BAC transgenic mice. Lily Kang and Claire Warriner contributed expert technical assistance to this project.

Correspondence should be addressed to Evelyn Lambe, Department of Physiology, University of Toronto, 1 King's College Circle, Toronto, ON M5S 1A8, Canada. E-mail: evelyn.lambe@utoronto.ca.

DOI:http://dx.doi.org/10.1523/ENEURO.0269-16.2016

Copyright (C) 2016 Tian et al.

This is an open-access article distributed under the terms of the Creative Commons Attribution 4.0 International, which permits unrestricted use, distribution and reproduction in any medium provided that the original work is properly attributed. liver, 1991; Linley et al., 2013; Goodfellow et al., 2014; Muzerelle et al., 2016). Therefore we can ask in a mouse model whether serotonin modulates prefrontal L6 pyramidal neurons known to play a role in task attention (Bailey et al., 2010; Guillem et al., 2011). In rodents, a substantial proportion of prefrontal L6 pyramidal neurons express 5- $\mathrm{HT}_{1 \mathrm{~A}}$ and/or 5- $\mathrm{HT}_{2 \mathrm{~A}}$ receptors (Chalmers and Watson, 1991; Pompeiano et al., 1992, 1994; Cornea-Hébert et al., 1999; Amargós-Bosch et al., 2004), with broad similarities in the expression of these 5-HT receptors in prefrontal L6 of human and nonhuman primates (de Almeida and Mengod, 2007, 2008; Mengod et al., 2015). Coexpression of $5-\mathrm{HT}_{1 \mathrm{~A}}$ and $5-\mathrm{HT}_{2 \mathrm{~A}}$ receptors is common in mPFC pyramidal neurons (Amargós-Bosch et al., 2004) and is observed in $48 \%$ of pyramidal neurons in L6 of mouse mPFC (Table 3 in Amargós-Bosch et al., 2004). Roles for 5-HT and $5-\mathrm{HT}_{2 \mathrm{~A}}$ receptors in attentional performance have been suggested (Carli and Samanin, 2000; Koskinen et al., 2000; Winstanley et al., 2003; Wingen et al., 2007). Furthermore, the serotonergic system is dysregulated in several brain disorders that are accompanied by disruptions of attention, including autism (Chugani, 2002; Kane et al., 2012), schizophrenia (Luck and Gold, 2008), and mood disorders (Marvel and Paradiso, 2004; Jans et al., 2007; Murrough et al., 2011).

Here, we investigated how mPFC L6 pyramidal neurons are modulated by 5-HT, how L6 excitation affects the two major classes of L5 interneurons, and how 5-HT modulates these internal mPFC circuits. Our results reveal a strong 5-HT-elicited inhibition of L6 pyramidal neurons mediated by $5-\mathrm{HT}_{1 \mathrm{~A}}$ receptors and a lesser, statedependent, and somewhat unexpected, contribution by $5-\mathrm{HT}_{2 \mathrm{~A}}$ receptors. We find that $\mathrm{L} 6$ pyramidal neurons robustly activate fast-spiking (FS) as well as non-fastspiking ( $\mathrm{nFS}$ ) interneurons in L5. Finally, we show that these intracortical circuits in mPFC are strongly suppressed by $5-\mathrm{HT}$.

\section{Materials and Methods}

\section{Experimental animals}

We used BAC transgenic Swiss Webster mice with expression of eGFP driven by the synaptotagmin 6 promoter (Syt6-EGFP EL71, MMRRC; RRID:MMRRC 010557-UCD) made by the GENSAT Project (Gong et al., 2003). L6 pyramidal neurons in mPFC strongly express eGFP and facilitate visual targeting of these neurons for recording (Tian et al., 2014). Syt6 mice were kept heterozygous, and there were no significant differences in their 5-HT responses compared to their wild-type littermate controls or wild-type C57BL/6 mice $\left(F_{(2,64)}=0.58, p\right.$ $=0.56$, one-way ANOVA). To investigate the downstream synaptic connection of prefrontal L6 pyramidal neurons, we crossed GENSAT epiphycan BAC transgenic mice expressing Cre-recombinase (Epyc-Cre KR363, a gift from Dr. Nathaniel Heintz at Rockefeller University; RRID: MMRRC_036145-UCD) with Ai:32 mice (Jackson Laboratories, Bar Harbor, ME; RRID:IMSR_JAX:024109) to achieve eGFP-channelrhodpsin-2 expression in prefrontal L6 neurons (Epyc-ChR2). Wild-type littermates of the Epyc-ChR2 were used as controls to ensure that the UV 
Table 1. Intrinsic electrophysiological properties of three groups of neurons recorded: pyramidal neurons in L6, FS interneurons in L5, and nFS interneurons in L5.

\begin{tabular}{llllll}
\hline & $\mathrm{RMP}(\mathrm{mV})$ & Input resistance $(\mathrm{M} \Omega)$ & Spike amplitude $(\mathrm{mV})$ & Peak firing frequency $(\mathrm{Hz})$ & $n$ \\
Layer 6 pyramidal neurons & $-90.2 \pm 0.6$ & $128.5 \pm 3.9$ & $83.1 \pm 0.6$ & $22.4 \pm 0.8$ & 122 \\
Layer 5 FS interneurons & $-85.2 \pm 1.2$ & $114.3 \pm 9.8$ & $59.5 \pm 2.2$ & $109.8 \pm 23.3$ \\
Layer 5 nFS interneurons & $-82.7 \pm 1.6$ & $235.9 \pm 30.0 *$ & $79.7 \pm 1.9 * *$ & $34.1 \pm 3.0 * *$
\end{tabular}

Neuronal properties shown are resting membrane potential (RMP), input resistance, spike amplitude, and peak firing frequency upon injection of a maximal suprathreshold current. Data are shown as mean \pm SEM. Comparisons between L5 FS and nFS interneurons: $* p<0.05, * * p<0.001$, unpaired $t$ tests.

light did not have effects in brain slices from mice lacking channelrhodopsin-2. Translating ribosome affinity purification (TRAP) and quantitative reverse-transcription (qRT)-PCR were used to confirm that Syt6 and Epyc-Cre neurons indeed represent an overlapping population of L6 glutamatergic neurons. All experimental animal procedures were performed in accordance with the University of Toronto and Rockefeller University Institutional Animal Care and Use Committee regulations.

\section{Electrophysiology}

Coronal brain slices $(400 \mu \mathrm{m})$ for electrophysiological recordings were obtained from adult male mice (postnatal 60 to 170 days; mean \pm SEM; $101 \pm 4$ days; $n=41$ mice). Brains were rapidly excised and chilled in $4^{\circ} \mathrm{C}$ oxygenated sucrose artificial cerebrospinal fluid (ACSF; $254 \mathrm{~mm}$ sucrose, $10 \mathrm{~mm}$ D-glucose, $24 \mathrm{~mm} \mathrm{NaHCO}_{3}, 2 \mathrm{~mm} \mathrm{CaCl}_{2}, 2$ $\mathrm{mm} \mathrm{MgSO}_{4}, 3 \mathrm{~mm} \mathrm{KCl}, 1.25 \mathrm{~mm} \mathrm{NaH}_{2} \mathrm{PO}_{4}$; $\mathrm{pH}$ 7.4). Coronal slices (400 $\mu \mathrm{m}$ thick, 2.34-0.74 mm from bregma) were cut on a Dosaka Linear Slicer (SciMedia, Costa Mesa, CA) and recovered in $30^{\circ} \mathrm{C}$ oxygenated ACSF (128 $\mathrm{mm} \mathrm{NaCl}, 10 \mathrm{~mm}$ D-glucose, $26 \mathrm{~mm} \mathrm{NaHCO}$, $2 \mathrm{~mm} \mathrm{CaCl}_{2}$, $2 \mathrm{~mm} \mathrm{MgSO}_{4}, 3 \mathrm{~mm} \mathrm{KCl}, 1.25 \mathrm{~mm} \mathrm{NaH}_{2} \mathrm{PO}_{4} ; \mathrm{pH}$ 7.4) for at least $2 \mathrm{~h}$.

Recovered slices were transferred to a perfusion chamber on the stage of a BX50W1 microscope (Olympus, Tokyo, Japan). ACSF was bubbled $\left(95 \% \mathrm{O}_{2}, 5 \% \mathrm{CO}_{2}\right.$ at room temperature) and perfused the chamber at a rate of 3-4 $\mathrm{ml} / \mathrm{min}$. In addition to recording from L6 pyramidal neurons based on neuronal morphology and anatomical landmarks in wild-type mice, L6 in Syt6 mice was landmarked with fluorescently identified eGFP-positive neurons (X-cite Series 120; Lumen Dynamics, Mississauga, Canada; Tian et al., 2014). Recording electrodes (2-4 M $\Omega$ ) containing $120 \mathrm{~mm}$ potassium gluconate, $5 \mathrm{~mm} \mathrm{KCl,} 2 \mathrm{~mm}$ $\mathrm{MgCl}_{2}, 4 \mathrm{~mm} \mathrm{~K}_{2}$-ATP, $0.4 \mathrm{~mm} \mathrm{Na}$-GTP, $10 \mathrm{~mm} \mathrm{Na} \mathrm{Na}_{2}$ phosphocreatine, and $10 \mathrm{~mm}$ HEPES buffer (adjusted to $\mathrm{pH} 7.3$ with $\mathrm{KOH}$ ) were used to patch L6 pyramidal neurons. Interneurons in L5 were identified visually based on their unique morphology in infrared differential interference contrast (small, circular somata) in contrast to L5 pyramidal neurons (oriented, triangular shaped somata, relatively thick apical dendrites toward pia). A subset of patched interneurons was filled with Alexa Fluor 594 (20 $\mu \mathrm{M})$ or Texas red dextran $(0.15 \%)$ in the patch solution for morphological confirmation of these criteria. Interneurons were further subclassified as FS or nFS based on their electrophysiological spike pattern and maximal spike frequency. Multiphoton images were acquired with a Ti: sapphire laser (Mai Tai, Spectra-Physics, Fremont, CA) using an Olympus Fluoview FV1000 microscope and an
Olympus XLPlan N $25 \times$ water-immersion objective. Neuronal membrane potential and holding current were recorded with an EPC10 (HEKA Electronik, Lambrecht/ Pfalz, Germany) and corrected for the liquid junction potential $(14 \mathrm{mV})$. All data were acquired at $20 \mathrm{kHz}$ and low-pass filtered at $3 \mathrm{kHz}$ with pClamp software (Molecular Devices, Palo Alto, CA). Threshold potentials for action potentials were detected using a derivative threshold of at least $20 \mathrm{mV} / \mathrm{ms}$, and action potential amplitude was calculated as the change in membrane potential from threshold to the peak of the action potential. Intrinsic properties of L6 pyramidal neurons, as well as L5 FS and nFS interneurons, are summarized in Table 1.

To examine the effects of 5-HT on L6 pyramidal neurons near rest and during spiking, we performed wholecell patch-clamp recording in voltage clamp at $-75 \mathrm{mV}$ and in current clamp with current injections to elicit either constant spiking $(2-3 \mathrm{~Hz})$ at baseline or an initial membrane potential of $-75 \mathrm{mV}$ before depolarizing current injections (1 s, 25-pA steps, 15-s intervals) were used to assess input-output relationships. For the latter experiment, the frequency of action potential firing was measured for each depolarizing current step and plotted against the magnitude of the injected current step.

\section{Pharmacology}

Acute responses to 5-HT were probed by bath application of 5-HT (serotonin creatinine sulfate, SigmaAldrich, St. Louis, MO; $10 \mu \mathrm{m} ; 30 \mathrm{~s}$ ) in ACSF. To examine the effect of 5-HT on the excitability of L6 pyramidal neurons, 5-HT (10 $\mu \mathrm{M})$ was bath applied until a steadystate response was reached, and remained in bath throughout the duration of the input-output test protocols ( $\sim 2$ min total application). Selective antagonists and agonists were from Tocris (Bristol, UK), except where mentioned. Antagonists for $5-\mathrm{HT}_{1 \mathrm{~A}}$ receptors (30 nM WAY100635, $10 \mu \mathrm{M}$ NAN-190) and 5- $\mathrm{HT}_{2 \mathrm{~A}}$ receptors (30 nM MDL100907; $2 \mu \mathrm{M}$ ketanserin; 300 nM to $3 \mu \mathrm{M}$ ritanserin) were applied in bath for $10 \mathrm{~min}$ before further experiments with 5-HT. There were no significant differences between effects of $300 \mathrm{~nm}$ and $3 \mu \mathrm{M}$ ritanserin, and results were grouped for analysis. TCB-2 was used as a specific agonist of $5-\mathrm{HT}_{2 \mathrm{~A}}$ receptors (300 $\mathrm{nM}$ to $\left.1 \mu \mathrm{M}\right)$. Other agonists and antagonists used for characterization of the 5-HT response in L6 neurons were as follows: $2 \mu \mathrm{M}$ tetrodotoxin (TTX) (Alomone Labs, Jerusalem, Israel), 20 $\mu \mathrm{M}$ 6-cyano-7-nitroquinoxaline-2,3-dione, $50 \mu \mathrm{M}$ D-2amino-5-phosphonovaleric acid, $100 \mu \mathrm{M}$ picrotoxin, $1 \mu \mathrm{M}$ CGP52432, and $10 \mu \mathrm{M}$ 8-OH-DPAT. 


\section{Optogenetic stimulation}

Channelrhodopsin-expressing neurons in Epyc-ChR2 mice were stimulated by blue LED light $(473 \mathrm{~nm})$ delivered by optic fiber (Thorlabs, Newton, NJ) mounted on a mechanical micromanipulator (Narishige International, East Meadow, NY). Light stimulation was directed directly to L6 of mPFC by targeted positioning of the optic fiber. Twenty light pulses (2-5 ms each) were delivered at $20 \mathrm{~Hz}$ to stimulate L6 neurons. This stimulation profile was sufficient to elicit robust activation of L6 pyramidal neurons expressing channelrhodopsin. In control experiments with brain slices from littermate mice lacking channelrhodopsin, light stimulation did not elicit a response in either L6 pyramidal neurons or L5 interneurons. Responses to light stimulation in L6 pyramidal neurons and L5 interneurons were measured in current-clamp from a baseline membrane potential of $-75 \mathrm{mV}$ held by continuous injection of depolarizing current. Response latency in L6 pyramidal neurons expressing channelrhodopsin was calculated from the time of light-on to the onset of the corresponding membrane potential change. Time-to-spike for L6 neurons from light-on was also calculated using the peak of the first resulting action potential. In L5 interneurons, the latency to response from L6 activation was calculated in voltage clamp as the time taken from light-on to the onset of the postsynaptic current, then corrected by the timeto-spike in L6 pyramidal neurons. Pairwise analysis of the effects of $5-\mathrm{HT}$ on the excitation of L5 interneurons by optogenetic activation of L6 were performed using light stimulus that was able to elicit at least four action potentials in patched L5 interneurons. Light stimulus intensity to elicit a baseline of at least four action potentials did not differ between FS and $\mathrm{nFS}$ interneurons $\left(t_{14}=1.4, p=\right.$ 0.18 , unpaired $t$ test).

\section{Statistical analysis}

All recordings were analyzed using Clampfit software (Molecular Devices). Statistical analyses were performed with GraphPad Prism (GraphPad Software, La Jolla, CA). Analyses performed were one-sample $t$ test, unpaired Student's $t$ test, paired Student's $t$ test, one-way ANOVA, two-way ANOVA, and two-way repeated-measures ANOVA. All tests were two-sided. Dunnett's multiple comparison tests were performed post hoc to compare changes in action potential firing in L6 neurons elicited by $5-\mathrm{HT}$. Sidak's multiple comparison tests were used to compare differences in spike frequency at individual injected current steps in the presence of 5-HT. All data are presented as mean \pm SEM.

\section{Translating ribosome affinity purification and quantitative RT-PCR}

Adult (8-12 weeks old) Epyc-Cre mice under ketamine/ xylazine $(100 / 10 \mathrm{mg} / \mathrm{kg})$ anesthesia received single bilateral stereotaxic injections of $0.25 \mu \mathrm{l}$ AAV-FLEXEGFPL10a virus $\left(3.75 \times 10^{12}\right.$ genome copies $\left./ \mathrm{ml}\right)$ into the mPFC (1.54 AP from bregma, 0.4 ML, -1.80 DV from dura). Animals were sacrificed in a controlled $\mathrm{CO}_{2}$ chamber 3 weeks after surgery, brains were rapidly dissected in ice-cold Hanks balanced salt solution containing $2.5 \mathrm{~mm}$ HEPES-KOH (pH 7.4), $35 \mathrm{~mm}$ glucose, $4 \mathrm{~mm} \mathrm{NaHCO}_{3}$, and
$100 \mu \mathrm{g} / \mathrm{ml}$ cycloheximide. The cortex was isolated from the rest of the brain, and each hemisphere was split along the coronal plane at the level of the genu of the corpus callosum ( $\sim 1.6 \mathrm{~mm}$ AP from bregma). The rostral portion was saved as the "PFC" and used for TRAP. Tissue from three mice (male and female) was pooled for each sample, and three biological replicates were collected. Polysome immunoprecipitations (IPs) were carried out as previously described (Schmidt et al., 2012; Heiman et al., 2014). Briefly, the tissue was homogenized in extraction buffer containing $10 \mathrm{~mm}$ HEPES-KOH (pH 7.4), $150 \mathrm{~mm} \mathrm{KCl,} 5 \mathrm{~mm} \mathrm{MgCl}_{2}, 0.5$ $\mathrm{mm}$ dithiothreitol, $100 \mu \mathrm{g} / \mathrm{ml}$ cycloheximide, RNasin (Promega, Madison, WI), and SUPERas-In (Invitrogen, San Diego, CA) RNase inhibitors, and complete EDTA-free protease inhibitors (Roche, Basel, Switzerland), and then cleared by centrifugation at $2000 \times g$. IGEPAL CA-630 (NP-40, Sigma-Aldrich) and diheptanoyl phosphatidylcholine (Avanti Polar Lipids, Alabaster, AL) were both added to the S2 supernatant for a final concentration of $1 \%$ each, followed by centrifugation at $20,000 \times \mathrm{g}$. Polysomes were immunoprecipitated from the S20 supernatant using $100 \mu \mathrm{g}$ monoclonal anti-EGFP antibodies $(50 \mu \mathrm{g}$ each of clones 19C8 and 19F7; Heiman et al., 2008) bound to biotinylated protein L (Pierce, Thermo Fisher, Waltham, MA) coated streptavidin-conjugated magnetic beads (Invitrogen), and washed in high salt buffer containing $10 \mathrm{mM}$ HEPES-KOH (pH 7.4), 350 mM KCl, $5 \mathrm{~mm} \mathrm{MgCl}_{2}$, 1\% IGEPAL CA-630, 0.5 $\mathrm{mM}$ dithiothreitol, $100 \mu \mathrm{g} / \mathrm{ml}$ cycloheximide, and RNasin RNase inhibitors (Promega). IPs were carried out overnight at $4^{\circ} \mathrm{C}$. Bound RNA was purified using the Absolutely RNA Nanoprep kit (Agilent, Santa Clara, CA). RNA was also purified from the pre-IP supernatant to serve as whole-PFC "input" samples. RNA quantity was measured with a Nanodrop 1000 spectrophotometer, and quality was assayed on an Agilent 2100 Bioanalyzer. Only samples with RNA integrity values $>7.0$ were used for qRT-PCR analysis. CDNA was synthesized from $15 \mathrm{ng}$ of IP or input total RNA using the Ovation qPCR System (NuGEN Technologies, Carlos, CA) following the manufacturer's protocol. qRT-PCR was performed on an Applied Biosystems StepOnePlus Fast RealTime PCR System using commercially available Taqman assays (Table 2) and following standard cycling conditions $\left(50^{\circ} \mathrm{C}\right.$ for $2 \mathrm{~min}, 95^{\circ} \mathrm{C}$ for $10 \mathrm{~min}$, then 40 cycles of $95^{\circ} \mathrm{C}$ for $15 \mathrm{~s}$ and $60^{\circ} \mathrm{C}$ for $\left.1 \mathrm{~min}\right)$. Ten nanograms of cDNA was used for each qRT-PCR reaction, and technical triplicates were run for each of the biological triplicates from TRAP IP and input samples. The mean $\mathrm{C}_{\mathrm{T}}$ for technical replicates was used for quantification. Data were normalized to Gapdh by the comparative $\mathrm{C}_{\mathrm{T}}\left(2^{-\Delta \Delta \mathrm{CT}}\right)$ method (Livak and Schmittgen, 2001). Data are presented as mean \pm SEM of biological triplicates. Statistical significance was calculated between the normalized expression values $\left(2^{-\Delta C T}\right)$ from the IP and input biological replicates for each gene by Student's $t$ test in Microsoft Excel.

\section{Results}

\section{Serotonin robustly inhibits L6 pyramidal neurons of mPFC}

Here, we investigated the electrophysiological consequences of 5-HT on pyramidal neurons in L6 of mPFC. 
Table 2. TaqMan gene expression assay.

\begin{tabular}{lll}
\hline Symbol & Gene name & Assay \\
Aldh1/1 & Aldehyde dehydrogenase 1 family, member L1 & Mm03048957_m1 \\
Cnp & Cyclic nucleotide phosphodiesterase 1 & Mm01306640_m1 \\
Foxp2 & Forkhead box P2 & Mm00475030_m1 \\
Gad1 & Glutamic acid decarboxylase 1 & Mm00725661_s1 \\
Gapdh & Glyceraldehyde-3-phosphate dehydrogenase & Mm99999915_g1 \\
Htr1a & 5-Hydroxytryptamine (serotonin) receptor 1A & Mm00434106_s1 \\
Htr2a & 5-Hydroxytryptamine (serotonin) receptor 2A & Mm00555764_m1 \\
Ntsr1 & Neurotensin receptor 1 & Mm00444459_m1 \\
Slc17a7 & Vesicular glutamate transporter 1 & Mm00812886_m1 \\
Syt6 & Synaptotagmin VI & Mm01308768_m1
\end{tabular}

Experiments in voltage clamp showed robust and replicable outward currents $(58.3 \pm 6.4 \mathrm{pA}, n=28$; Fig. $1 A, B)$ in response to bath application of $5-\mathrm{HT}(10 \mu \mathrm{M}, 30 \mathrm{~s})$. These 5-HT-elicited currents were dose-dependent, with an $\mathrm{EC}_{50}$ of $5.7 \pm 0.1 \mu \mathrm{M}\left(n=7, r^{2}=0.9\right)$. The lack of significant change in these responses to blocking voltagegated sodium channels with TTX $\left(2 \mu \mathrm{M}, 10 \mathrm{~min}\right.$ in bath; $t_{3}=$ 1.2, $p=0.3, n=4$, paired $t$ test), to blocking AMPA, NMDA, and GABA-A receptors (6-cyano-7-nitroquinoxaline-2,3dione [20 $\mu \mathrm{M}$ ], 2-amino-5-phosphonovaleric acid [50 $\mu \mathrm{M}$ ], picrotoxin [100 $\mu \mathrm{M}$ ], $t_{6}=0.5, p=0.6, n=7$, paired $t$ test; Fig. $1 A, D)$, as well as to blocking these synaptic receptors together with GABA-B blockade with CGP52432 (10 $\mu \mathrm{M} ; t_{3}$ $=0.27, p=0.8, n=4$, paired $t$ test) suggest direct mediation by 5-HT receptors on L6 pyramidal neurons themselves. We found that the specific 5- $\mathrm{HT}_{1 \mathrm{~A}}$ antagonist WAY100635 (30 nM, $10 \mathrm{~min}$ in bath) significantly reduced the 5-HTmediated current in L6 pyramidal neurons ( $\sim 70 \%$ reduction to $18.3 \pm 2.6 \mathrm{pA}, t_{18}=4.9, p<0.0001, n=19$, unpaired $t$ test; Fig. 1B-D). The 5- $\mathrm{HT}_{1 \mathrm{~A}}$ agonist $8-\mathrm{OH}-\mathrm{DPAT}(10 \mu \mathrm{M})$ elicited outward currents of similar magnitude to the 5-HT current in L6 pyramidal neurons (5-HT, $61.2 \pm 12.8 \mathrm{pA}$; 8-OH-DPAT, $48.5 \pm 11.1 \mathrm{pA}, t_{5}=1.6, p=0.2, n=6$, paired $t$ test).

To investigate the functional effects of 5-HT on L6 pyramidal neurons during excitation, we used currentclamp and bath-applied 5-HT in the presence of injected positive depolarizing current sufficient to elicit action potential firing (2-3 Hz). Under these conditions, 5-HT hyperpolarized L6 neurons $(-16.3 \pm 1.6 \mathrm{mV}, n=17)$ and fully and significantly inhibited action potential firing in every recorded neuron $\left(t_{7}=13.5, p<0.0001, n=8\right.$, paired $t$ test; Fig. 1E, $\mathrm{H}, \mathrm{I})$. This suppression was repeatable in the same neuron after washout and was not affected by the presence of synaptic blockers (Fig. 1E, H, I). Antagonism of 5- $\mathrm{HT}_{1 \mathrm{~A}}$ receptors by WAY100635 significantly reduced the 5 -HT-mediated hyperpolarization $\left(-7.8 \pm 0.7 \mathrm{mV}, t_{18}=5.0, p<0.0001, n=19\right.$, unpaired $t$ test; Fig. 1F-I). Unexpectedly, however, 5-HT still robustly and significantly inhibited action potential firing in every neuron ( $t_{13}=12, p<0.0001, n=14$, paired $t$ test; Fig. $1 \mathrm{~F}-\mathrm{I})$. This strong and significant suppression of L6 spiking by $5-\mathrm{HT}$ was also observed in the presence of synaptic blockers ( $t_{3}=4.8, p=0.02, n=4$, paired $t$ test). These data show a robust and repeatable 5-HT inhibition of L6 neurons by $5-\mathrm{HT}$ with a component mediated by $5-\mathrm{HT}_{1 \mathrm{~A}}$ receptors. However, the continued suppression of action potential firing by 5-HT after blockade of 5- $\mathrm{HT}_{1 \mathrm{~A}}$ receptors suggests the involvement of an additional 5-HT-mediated mechanism for inhibition of MPFC L6 pyramidal neurons.

\section{Serotonergic 5-HT1A and 5-HT2A receptors cooperate in inhibiting L6 pyramidal neurons}

To interrogate this unidentified component of 5-HT inhibition of L6 pyramidal neurons, action potentials were elicited by a series of incremental square depolarizing pulses before and during 5-HT application. Despite the stronger activation, 5-HT still significantly reduced spike frequency at each injected current step, as shown by the significant right-shift in the input-output curve (inhibitory effect of 5-HT: $F_{(1,168)}=31, p<0.0001, n=22$, repeated measures two-way ANOVA; Fig. 2A). Post hoc tests show that significantly fewer action potentials were elicited by input current in 5-HT compared with baseline at every step ( $p<0.05$, Sidak's multiple comparisons test). Of note, the 25-pA step was suprathreshold for 17 of 22 neurons at baseline and only 3 of 22 neurons in 5-HT ( $p<$ 0.0001 , Fisher's exact test). Spiking was significantly restored after a 5-min washout of 5-HT $\left(F_{(1,168)}=28, p<\right.$ 0.0001 , repeated-measures two-way ANOVA). Activation of 5- $\mathrm{HT}_{1 \mathrm{~A}}$ receptors by 8-OH-DPAT also significantly suppressed firing of L6 neurons (50-pA current injection, baseline, $4.0 \pm 1.1 \mathrm{~Hz}$; 8-OH-DPAT, $0.8 \pm 0.6 \mathrm{~Hz} ; t_{5}=$ 5.3, $p=0.003, n=6$, paired $t$ test), as did 8-OH-DPAT across a range of depolarizing steps $\left(F_{(5,12)}=35.7, p<\right.$ 0.0001 , two-way repeated measures ANOVA, data not shown).

Yet, further experiments suggest that 5-HT recruits an additional receptor beyond $5-\mathrm{HT}_{1 \mathrm{~A}}$ to inhibit the excitability of L6 pyramidal neurons. Significant 5-HT suppression of L6 neuronal excitability continued after antagonism of $5-\mathrm{HT}_{1 \mathrm{~A}}$ receptors by WAY100635, with a significantly right-shifted input-output curve (inhibitory effect of 5-HT in WAY100635: $F_{(1,72)}=72, p<0.0001, n=10$, repeated measures two-way ANOVA; Fig. 2B). Consistent with our above data, this result suggests the participation of at least one additional subtype of 5-HT receptor in inhibiting L6 pyramidal neurons. The $5-\mathrm{HT}_{2 \mathrm{~A}}$ receptors that are coexpressed with $5-\mathrm{HT}_{1 \mathrm{~A}}$ receptors in $48 \%$ of $\mathrm{L} 6$ pyramidal neurons in mouse mPFC (Table 3 in Amargós-Bosch et al., 2004) are an unusual candidate to underlie the 5-HT-mediated suprathreshold suppression of spiking. These receptors typically recruit excitatory effectors (Lambe and Aghajanian, 2001; Zhang and Arsenault, 
A

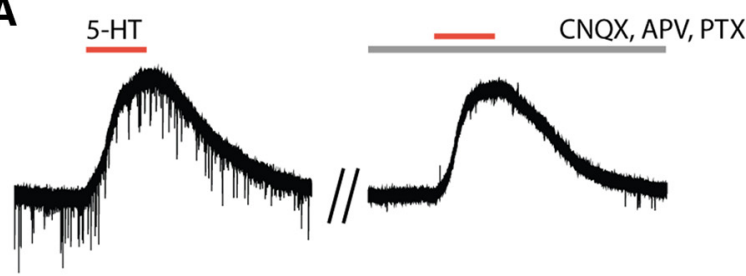

B
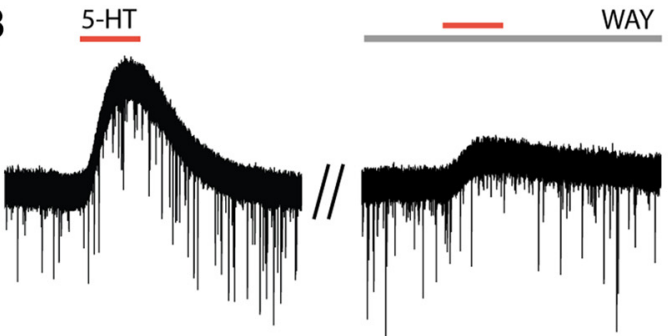

C

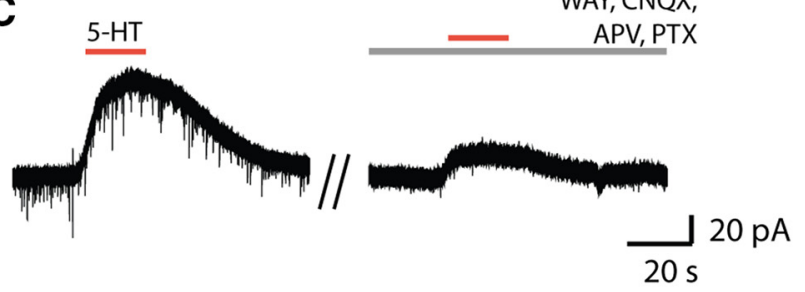

D

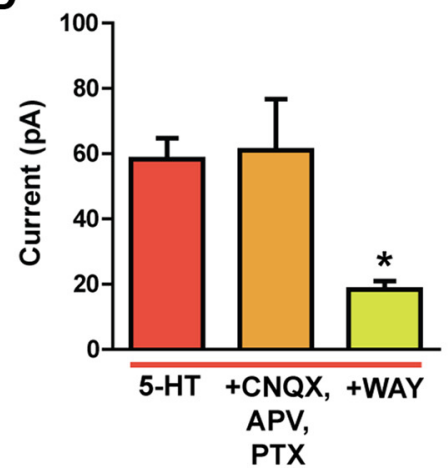

H

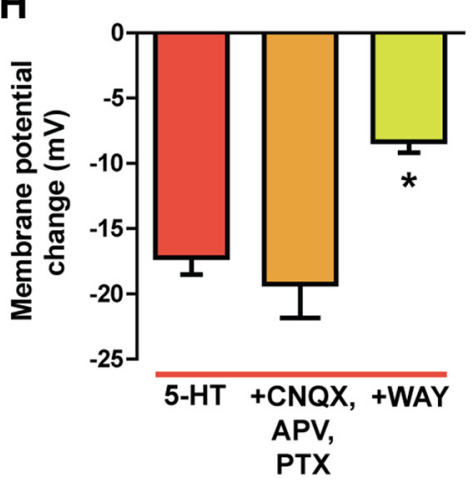

E
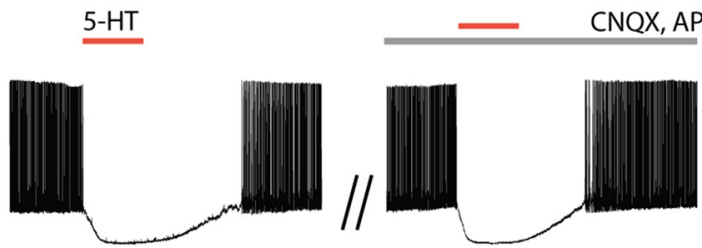

F
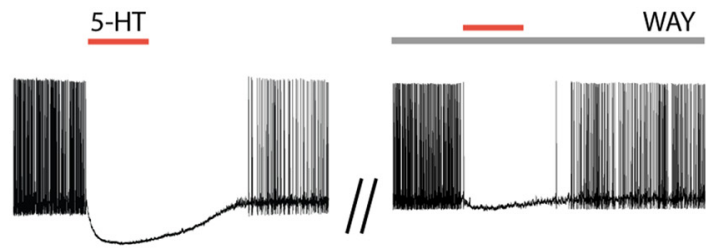

G

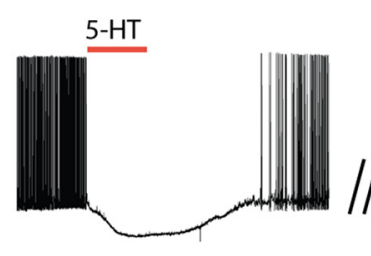

Figure 1. 5-HT inhibits L6 pyramidal neurons of medial prefrontal cortex. Responses to 5-HT were probed in voltage-clamp and current-clamp by bath application of 5-HT. Representative voltage-clamp traces of the 5-HT response in L6 pyramidal neurons show that responses to 5-HT are stable and persist in the presence of synaptic blockers $(\boldsymbol{A})$, are significantly suppressed by WAY100635 $(\boldsymbol{B})$, and are similarly suppressed by a combination of WAY100635 and synaptic blockers $(\boldsymbol{C})$. $\boldsymbol{D}, 5$-HT elicits strong outward currents on L6 pyramidal neurons of mPFC $(n=28)$ that can be pharmacologically modulated $\left(F_{(2,53)}=11.8, p<0.0001\right.$, one-way ANOVA). Post hoc analyses show that these currents persist in the presence of synaptic blockers $(q=0.2, p>0.05, n=7$, Dunnett's multiple comparison test) but are significantly suppressed by WAY100635 ( $q=4.6, p<0.0001, n=19)$. Responses to 5-HT were probed in current-clamp in L6 pyramidal neurons of medial prefrontal cortex with current injection to elicit steady firing $(\sim 2-3 \mathrm{~Hz})$ at baseline. Representative current-clamp traces show that responses to 5-HT are inhibitory, repeatable, and unaffected by synaptic blockers (E) and not fully blocked by WAY100635 $(\boldsymbol{F})$ or by WAY100635 and synaptic blockers $(\boldsymbol{G})$. $\boldsymbol{H}$, L6 pyramidal neurons of mPFC are strongly hyperpolarized by 5-HT $(n=26)$. Post hoc analyses of pharmacological effects on this hyperpolarization $\left(F_{(2,50)}=17, p<0.0001\right.$, one-way ANOVA) show that this inhibition is unaffected by synaptic blockers ( $q=0.8, p>0.5, n=6$, Dunnett's multiple comparison test) but greatly reduced by WAY100635 $(q=5.4, p<0.0001, n=21)$. I, Action potential firing was significantly affected by 5 -HT $\left(F_{(4,103)}=37, p<0.0001\right.$, one-way ANOVA). Post hoc analyses reveal that baseline firing was strongly suppressed by $5-\mathrm{HT}(q=9$, $p<0.0001, n=17$, Dunnett's multiple comparison test) and remained suppressed by 5 -HT in synaptic blockers ( $q=6.1, p<0.0001$, $n=6)$. The suppression was not blocked by WAY100635 ( $q=8.8, p<0.0001, n=16)$ and returned to baseline levels after washout of $5-\mathrm{HT}(q=2.3, p>0.05, n=36)$.

2005; Weisstaub et al., 2006; Benekareddy et al., 2010; Weber and Andrade, 2010; Avesar and Gulledge, 2012), although previous work has demonstrated the capacity of serotonin and $5-\mathrm{HT}_{2 \mathrm{~A}}$ agonists to exert direct inhibitory effects through 5- $\mathrm{HT}_{2 \mathrm{~A}}$ receptors or heteromers (Carr et al., 2002; Kurrasch-Orbaugh et al., 2003; GonzálezMaeso et al., 2007; Moreno et al., 2011). We found that adding the selective $5-\mathrm{HT}_{2 \mathrm{~A}}$ antagonist MDL100907 abol- 
A

\section{Baseline 5-HT}

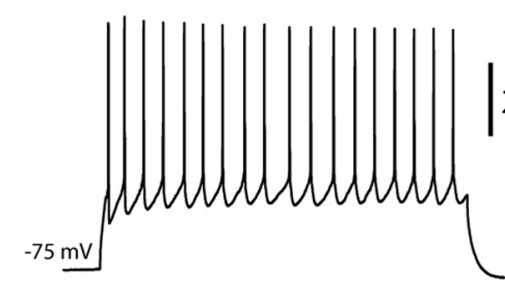

B

+ WAY

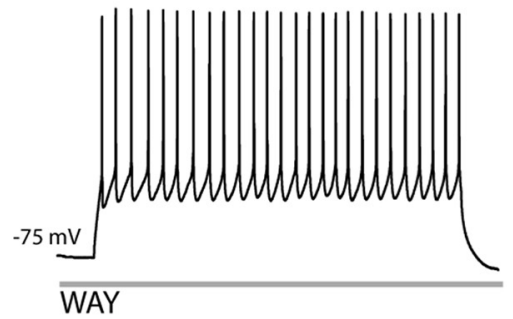

C

+ WAY and MDL

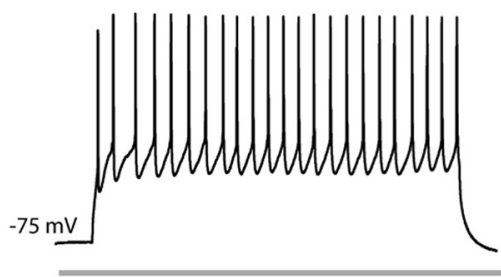

WAY, MDL
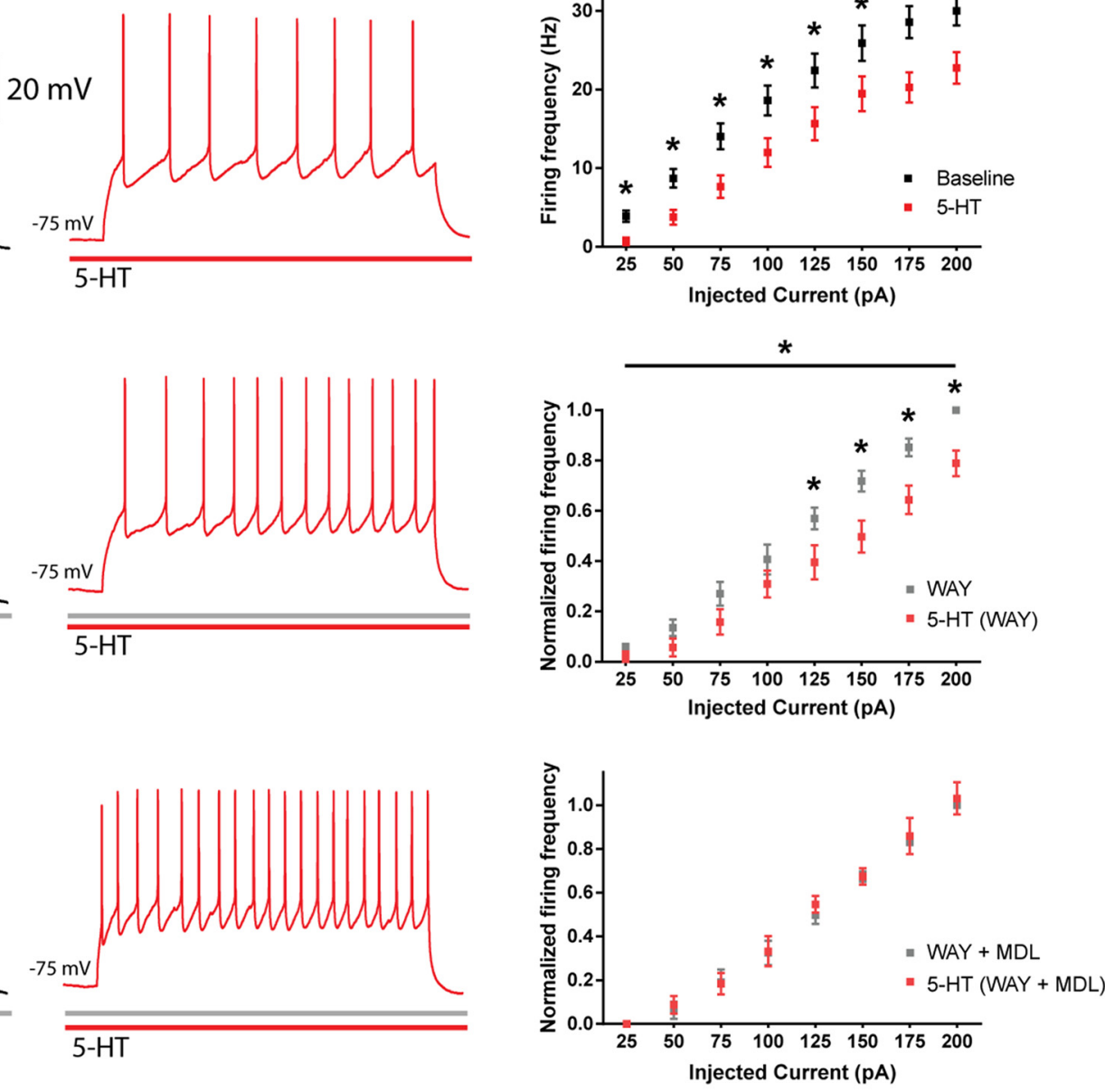

\section{TCB-2}
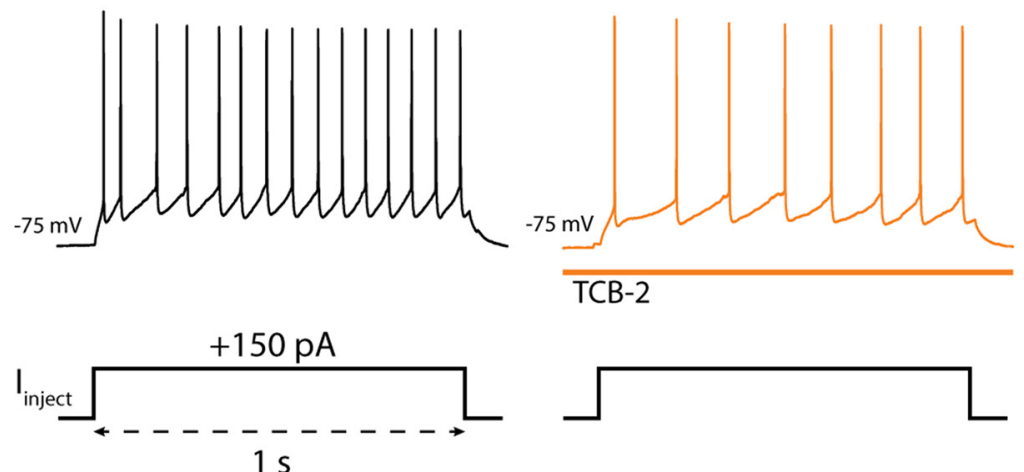

Figure 2. Combined activation of serotonergic 5- $\mathrm{HT}_{1 \mathrm{~A}}$ and 5- $\mathrm{HT}_{2 \mathrm{~A}}$ receptors mediate inhibition of $\mathrm{L} 6$ neuronal excitability at suprathreshold potentials. Incremental current steps were injected into patched L6 pyramidal neurons, and their output in firing frequency was measured. Shown are representative recordings of the response to a 150-pA current step in single L6 pyramidal neurons (left) and the response to the same 150-pA current step in the presence of 5-HT (middle). The input-output relationship for each group is plotted (right). $\boldsymbol{A}$, The input-output relationship of L6 pyramidal neurons is significantly right-shifted by 5 -HT $\left(F_{(1,168)}=31, p<0.0001\right.$, repeated-measures two-way ANOVA). Post hoc analysis showed significantly fewer elicited action potentials at every input step $(p<0.05$, Sidak's multiple comparisons test). $\boldsymbol{B}$, L6 excitability is significantly suppressed by $5-\mathrm{HT}$ in the presence of WAY100635 $\left(p<0.0001, F_{(1,72)}=72\right.$, repeated-measures two-way ANOVA), an effect especially prominent at higher input steps (125- to 200-pA steps, $p<0.05$, Sidak's multiple comparisons test). C, L6 suppression by $5-\mathrm{HT}$ is fully blocked by simultaneous blockade of both $5-\mathrm{HT}_{1 \mathrm{~A}}$ and $5-\mathrm{HT}_{2 \mathrm{~A}}$ receptors by specific antagonists WAY100635 and MDL100907 $\left(F_{(1,32)}=0.8, p=0.4\right.$, repeated-measures two-way ANOVA). D, TCB-2, a selective 5-HT $2 \mathrm{~A}$ receptor agonist, inhibits L6 neuronal firing $\left(F_{(1,80)}=24, p<0.0001\right.$, repeated-measures two-way ANOVA), also more prominently at higher input steps (125- to 200-pA steps, $p<0.05$, Sidak's multiple comparisons test). 
A

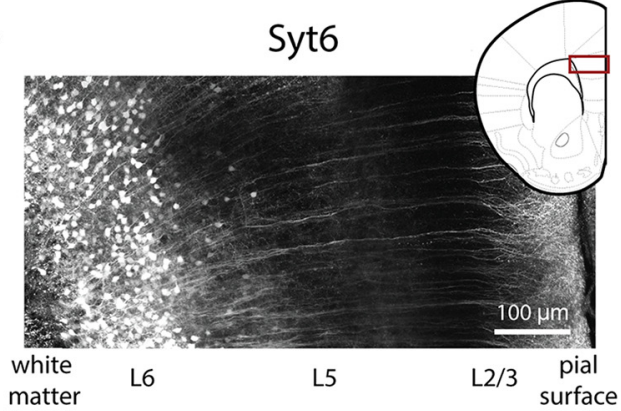

B

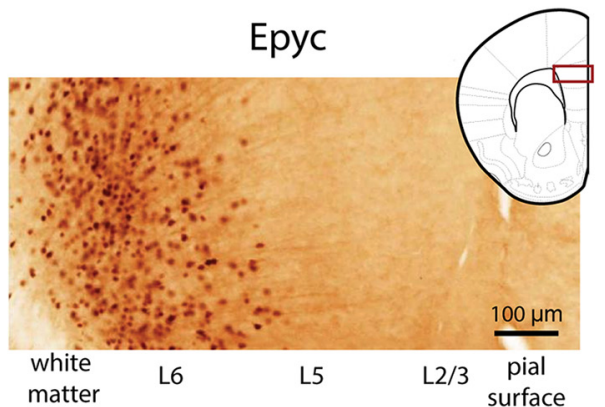

C

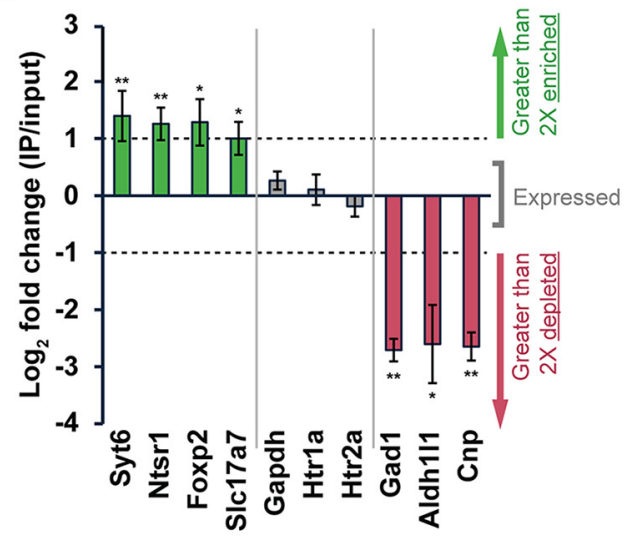

Figure 3. Characterization of L6 neurons in medial prefrontal cortex (mPFC) expressing synaptotagmin 6 and epiphycan. $\boldsymbol{A}$, Neurons expressing eGFP driven by the synaptotagmin-6 (Syt6) BAC promoter are localized to L6 pyramidal neurons in the prelimbic region of $\mathrm{mPFC}$. $\boldsymbol{B}$, EGFP is also seen in L6 pyramidal neurons in prelimbic mPFC by anti-EGFP immunohistochemistry in Epyc-Cre mice crossed to a Cre-dependent eGFP reporter. Image is adapted from www.gensat.org. $\boldsymbol{C}$, Quantification (mean \pm SEM) by qRT-PCR of the expression of selected genes in MPFC Epyc-vTRAP IP samples compared with whole PFC input. Positive values indicate enrichment in the IP, and negative values indicate depletion. Dotted lines indicate a twofold difference in either direction. Green bars, genes that are >2-fold enriched in the Epyc cells; red bars, genes that are >2-fold depleted; gray bars, genes expressed at levels similar to the rest of PFC. Of note, mRNAs for serotonin receptors Htr1a and Htr2a were expressed, but not enriched, in Epyc cells, a not-unexpected finding given the expression of $5-\mathrm{HT}_{1 \mathrm{~A}}$ and $5-\mathrm{HT}_{2 \mathrm{~A}}$ in other populations of neurons in mouse mPFC beyond L6. $* p$ $<0.05 ; * * p<0.01$ by Student's $t$ test.

ished the remaining inhibitory effects elicited by $5-\mathrm{HT}$ on the input-output of L6 neurons (no significant effects of 5-HT in WAY100635 and MDL100907: $F_{(1,32)}=$ $0.8, p=0.4, n=5$, repeated-measures two-way ANOVA; Fig. 2C). A similar blockade of the inhibitory effects of 5-HT on L6 neurons was also seen when other $5-\mathrm{HT}_{2 \mathrm{~A}}$ antagonists were applied together with WAY100635, such as ketanserin $(2 \mu \mathrm{M})$ or ritanserin (300 nм to $1 \mu \mathrm{M} ; F_{(1,48)}=0.3, p=0.6, n=7$, repeatedmeasures two-way ANOVA).

To probe further the power of $5-\mathrm{HT}_{2 \mathrm{~A}}$ receptors to inhibit L6 pyramidal neurons in MPFC, we applied a potent $5-\mathrm{HT}_{2 \mathrm{~A}}$ agonist, TCB-2 (300 $\mathrm{nM}$ to $1 \mu \mathrm{M}$ ). Here, we observed a strong inhibition of L6 neuronal excitability, with a significant right-shift of the input-output relationship (inhibitory effect of TCB-2: $F_{(1,80)}=24, p<0.0001, n$ $=11$, repeated-measures two-way ANOVA; Fig. 2D). Pretreatment with MDL100907 abolished the inhibitory effect of TCB-2 $\left(F_{(1,16)}=1.2, p=0.3, n=3\right.$, repeated-measures two-way ANOVA). Taken together, our results suggest that $5-\mathrm{HT}$ inhibition of mPFC L6 pyramidal neurons is mediated by a combination of $5-\mathrm{HT}_{1 \mathrm{~A}}$ and $5-\mathrm{HT}_{2 \mathrm{~A}}$ receptors acting in concert. However, substantial future work will be needed to elucidate the mechanisms by which these receptors individually and together work to suppress the excitability of L6 pyramidal neurons.

\section{Transgenic mouse for examining the effect of $L 6$ activation on L5 interneurons}

It has been shown that L6 pyramidal neurons in primary sensory cortex exert robust gain modulation over superficial layers of the cortical column (Olsen et al., 2012) through strong connections to FS interneurons (VélezFort and Margrie, 2012). In mPFC, recent work has demonstrated the importance of FS interneurons in L5 for performance on attention tasks (Kim et al., 2016). To investigate the effects of prefrontal L6 activation on its targets in the cortical column, we used the Epyc-Cre BAC transgenic mice that target Cre recombinase to L6 cells in mPFC, then generated Epyc-Cre;Ai:32 mice (Epyc-ChR2) to obtain expression of channelrhodopsin in those cells. Figure $3 A$ and $B$ shows a similar distribution of L6 cells labeled by Syt6-eGFP fluorescence, used in the initial electrophysiology experiments, and by Epyc-Cre, used for the optogenetic experiments. Because of the lack of reliable histological markers for L6 pyramidal neurons in mPFC, the TRAP technique (Heiman et al., 2008; Doyle et al., 2008) was used to interrogate the identity of the Epyc-Cre cells. An adeno-associated virus (AAV) vector (AAV-FLEX-EGFPL10a) to express EGFP-tagged ribosomal protein L10a (EGFPL10a) in a Cre-dependent manner was injected into the mPFC of Epyc-Cre mice, and anti-EGFP immunoprecipitations were performed to iso- 
late tagged polysomes. Bound mRNAs were then purified and analyzed by qRT-PCR. These data are plotted in Figure $3 C$. There was a significant enrichment for the excitatory neuron marker, S/c17a7 (VGluT1), in the Epyc TRAP IP compared with whole PFC input. Two genes known to be expressed in L6 corticothalamic cells, Ntsr1 (Gong et al., 2007; Olsen et al., 2012; Mease et al., 2014) and Foxp2 (Ferland et al., 2003), were also significantly enriched in IP samples. In contrast, genes that label inhibitory interneurons (Gad1), astrocytes (Aldh1/1), or oligodendrocytes (Cnp) were significantly depleted from the IPs. Taken together, these data suggest that Epyc-Cre labels a population of L6 corticothalamic pyramidal cells. Importantly, the qPCR also revealed that Syt6 was highly enriched in the Epyc cells, demonstrating that the Syt6eGFP and Epyc-Cre mice label an overlapping population of neurons. In contrast, levels of the housekeeping gene Gapdh were found to be similar between the TRAP IPs and whole PFC input. Similar results were obtained for the 5-HT receptors, Htr1a and Htr2a, suggesting these genes are expressed but not enriched in the Epyc cells, which was not surprising given the expression of $5-\mathrm{HT}_{1 \mathrm{~A}}$ and $5-\mathrm{HT}_{2 \mathrm{~A}}$ in other populations of neurons in mouse mPFC beyond L6 (Chalmers and Watson, 1991; Pompeiano et al., 1992, 1994; Cornea-Hébert et al., 1999; AmargósBosch et al., 2004).

\section{Optogenetic activation of L6 pyramidal neurons is sensitive to serotonin}

In electrophysiological experiments from Epyc-ChR2, we found that L6 pyramidal neurons, but not nonpyramidal neurons, were strongly depolarized upon light stimulation $(473 \mathrm{~nm}$, train of 2-ms-duration pulses at $20 \mathrm{~Hz}$ for $1 \mathrm{~s}$ ), which was targeted to L6 mPFC with optic fiber (Fig. $4 A, B)$. In contrast, prefrontal L6 neurons of littermate controls lacking channelrhodopsin did not respond to light stimulation. To verify that L6 pyramidal neurons were directly activated by light stimulation, we measured the kinetics of their light-evoked excitation. L6 pyramidal neurons rapidly responded to light ( $<1$-ms latency to onset of excitation), consistent with direct activation through expressed channelrhodopsin (Ernst et al., 2008). This response rises to threshold, giving an action potential peak at $4.7 \pm 0.7 \mathrm{~ms}$ (time to L6 spike; $n=5$ ).

The channelrhodopsin-expressing L6 neurons from Epyc-ChR2 mice showed sensitivity to $5-\mathrm{HT}$ similar to that of the Syt6-eGFP cells in the above experiments. Light-mediated excitation of Epyc-ChR2 L6 neurons was significantly suppressed in the presence of 5-HT $\left(F_{(1,24)}=10.3, p<0.004\right.$, repeated-measures two-way ANOVA).

\section{Optogenetic activation of L6 drives excitation of L5 interneurons}

Because fast-spiking GABAergic neurons in mPFC are important to normal performance in attention tasks (Kim et al., 2016), we patched mPFC L5 interneurons in Epyc-ChR2 mice as potential downstream projection targets of L6 pyramidal neurons. We anticipated that light-mediated activation of L6 pyramidal neurons by targeted optic fiber would elicit postsynaptic responses in patched L5 interneurons. GABAergic interneurons were visually identified by their morphology and intrinsic properties, and their spiking patterns in response to depolarizing current steps were documented. This experimental protocol yielded two distinct populations of interneurons: FS cells with characteristic action potential firing $>40 \mathrm{~Hz}$ and $\mathrm{nFS}$ cells that displayed lowthreshold firing characteristics. The intrinsic properties of these neurons are illustrated in Table 1. A subset of patched interneurons ( $n=6$ FS interneurons, $n=5 \mathrm{nFS}$ interneurons) was filled with Alexa Fluor $594(20 \mu \mathrm{M})$ or Texas red dextran $(0.15 \%)$ in the patch solution to verify their morphology. Filled FS (6/6) and nFS (5/5) interneurons were morphologically characteristic of the respective subtypes of interneurons in cortex (Markram et al., 2004; Ascoli et al., 2008).

All of the L5 FS $(n=19)$ and $\mathrm{nFS}(n=22)$ interneurons recorded responded to light stimulation positioned over L6 $(20 \mathrm{~Hz}, 2-$ to 5 -ms pulse duration, 20-pulse train). Light stimulation over other cortical layers did not produce a response. Latency between time to L6 spike and response onset in L5 interneurons was $1.1 \pm 0.3 \mathrm{~ms}$, consistent with a monosynaptic connection (Markram et al., 1997; Feldmeyer et al., 2005; Frick et al., 2008) from L6 (Fig. 4C). Activation of both FS and $\mathrm{nFS}$ interneurons by optogenetic stimulation of L6 was substantially and significantly reduced by $\operatorname{TTX}\left(F_{(1,80)}=19, p<0.0001\right.$, twoway ANOVA). Together with the need for light activation over L6, it appears that channelrhodopsin is predominantly localized in the L6 pyramidal cell bodies and not in axon terminals impinging on the L5 interneurons.

Light stimulation over L6 elicited action potential firing in $100 \%$ of FS cells (Fig. $4 D$ ) and $70 \%$ of nFS cells. The firing pattern elicited in these two types of interneurons was different, with a greater number of spikes seen at the start of L6 stimulation in FS neurons and a more evenly distributed firing pattern observed in the $\mathrm{nFS}$ neurons (Fig. 5). The minimal L6 light to elicit a suprathreshold excitatory response did not differ significantly between FS and $\mathrm{nFS}$ L5 interneurons $\left(t_{14}=0.2, p=0.8\right.$, unpaired $t$ test), despite a significant difference in input resistance $\left(t_{14}=\right.$ $4.3, p=0.0006$, unpaired $t$ test; Table 1$)$. In response to maximal L6 light stimulation of L6, FS interneurons fired more action potentials than $\mathrm{nFS}$ interneurons $\left(t_{14}=4.4, p\right.$ $=0.0007$, unpaired $t$ test).

\section{Serotonin suppresses L6 activation of L5 interneurons}

Because optogenetic stimulation in L6 resulted in robust and highly stable excitation of interneurons in $\mathrm{L} 5$ that did not decrease over time at baseline conditions $\left(t_{11}=\right.$ $0.8, p=0.4$, paired $t$ test; Fig. $6 A$ ), it was straightforward to test the effect of $5-\mathrm{HT}$ on this local circuit. We found that 5-HT strongly and significantly suppressed the number of action potentials elicited in L5 interneurons by optogenetic activation of L6 (FS cells: $t_{8}=3.8, p=0.005$, $n=9$, paired $t$ test; nFS cells: $t_{6}=5.7, p=0.001, n=7$, paired $t$ test; Fig. 6B). Of note, this suppression appeared to arise from 5-HT effects in L6, since interneurons in L5 showed minimal direct responses to $5-\mathrm{HT}$ at $-75 \mathrm{mV}(2.7$ 
A

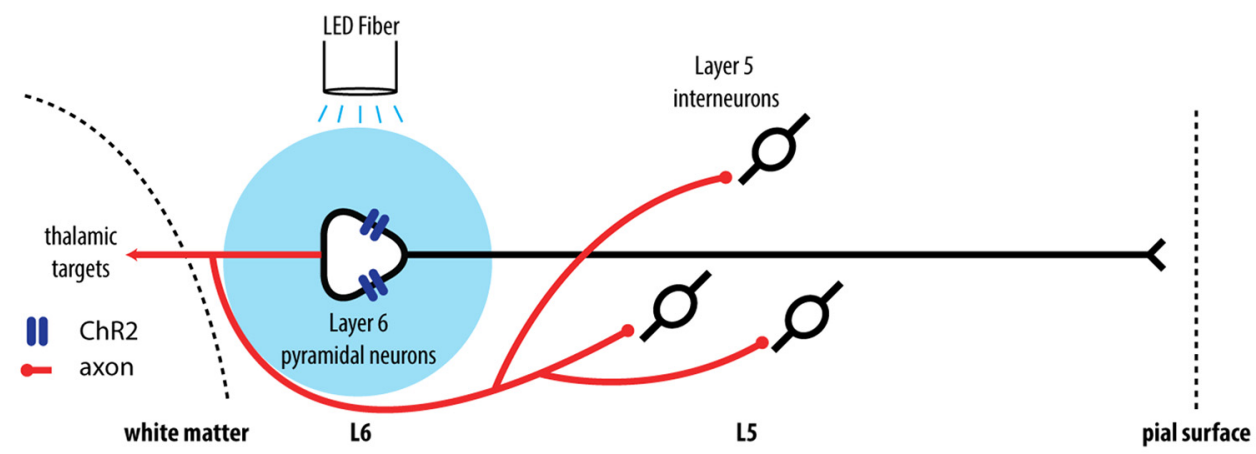

B

Layer 6 pyramidal neuron
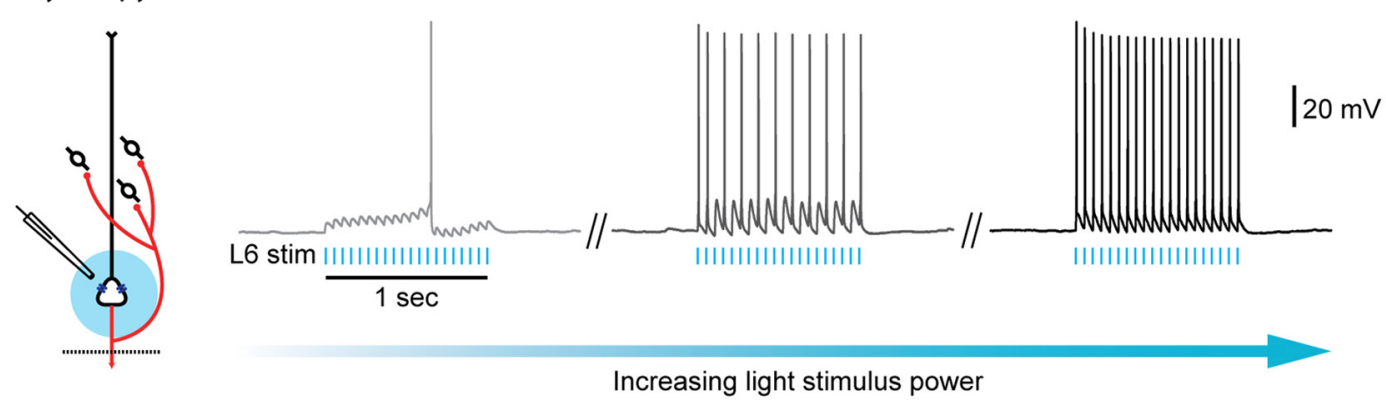

C Postsynaptic target cell of layer 6 pyramidal neurons

(Layer 5 interneuron)
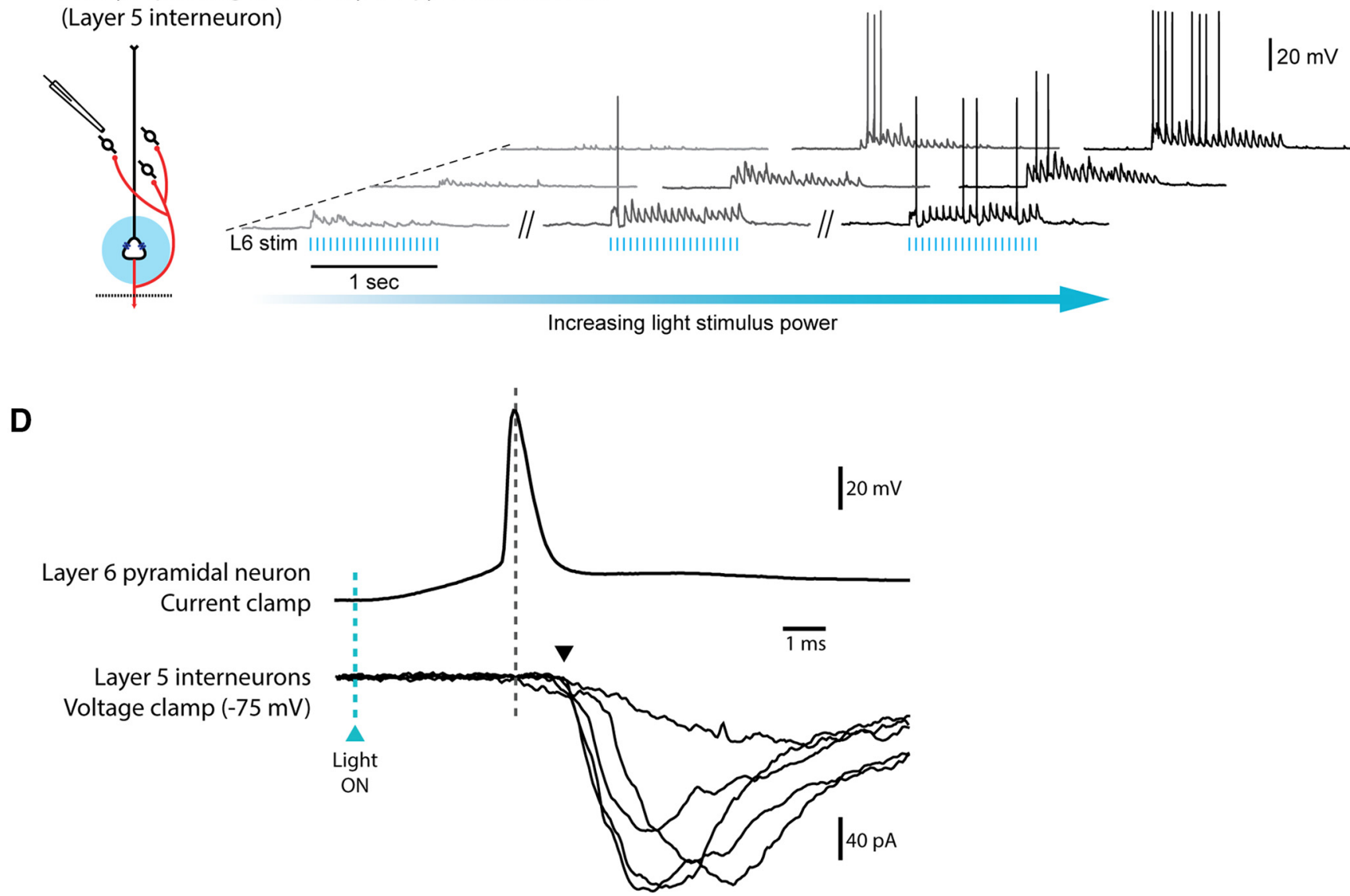

Figure 4. Optogenetic activation of L6 pyramidal neurons of medial prefrontal cortex excites L5 interneurons. $\boldsymbol{A}$, Schematic representation of light activation of L6 pyramidal neurons of medial prefrontal cortex in Epyc-ChR2 mice with axons projecting to L5 interneurons. $\boldsymbol{B}$, Channelrhodopsin-expressing pyramidal L6 neurons were robustly excited by targeted light stimulation 
continued

over L6. The effects of increasing L6 light power are shown for one example L6 pyramidal neuron. $\boldsymbol{C}$, Light activation of L6 robustly excited L5 interneurons. The effects of increasing L6 light power are shown for three different L5 interneurons. $\boldsymbol{D}$, Top, close-up of the initial light-evoked action potential in L6 to show the timing from onset of light (blue dotted line) to peak of the spike (black dotted line). Scale bar: $20 \mathrm{mV}, 1 \mathrm{~ms}$. Note: In L6 the onset of depolarization from light is $<1 \mathrm{~ms}$. Bottom, voltage-clamp recording showing the light-evoked postsynaptic response in a L5 interneuron to demonstrate response latency. Scale bar: 40 pA, 1 ms. Postsynaptic responses in L5 interneurons were initiated $1.1 \pm 0.3$ ms after initial spike of L6 pyramidal neurons, as indicated by an arrow.

$\pm 6.0 \mathrm{pA}, p=0.9, n=29$, one-sample $t$ test). Furthermore, these interneurons showed no change to spiking elicited by depolarizing steps of current amplitudes similar to those elicited by optogenetic stimulation of L6 (FS interneurons, $F_{(1,9)}=3.1, p=0.1$, repeated-measures two-way ANOVA; $\mathrm{nFS}$ interneurons, $F_{(1,18)}=3.4, p=0.1$, repeated-measures two-way ANOVA; data not shown). The excitation of L5 interneurons by L6 optogenetic activation was no longer sensitive to $5-\mathrm{HT}$ upon blockade of $5-\mathrm{HT}_{1 \mathrm{~A}}$ and $5-\mathrm{HT}_{2 \mathrm{~A}}$ receptors $\left(t_{15}=0.9, p=0.4\right.$, paired $t$ test, $n=10$ FS interneurons, $n=6 \mathrm{nFS}$ interneurons; Fig. $6 C)$. Overall, these results demonstrate the ability of L6 pyramidal neurons to excite a diverse group of inhibitory interneurons in L5 and the sensitivity of this effect to suppression by serotonergic $5-\mathrm{HT}_{1 \mathrm{~A}}$ and $5-\mathrm{HT}_{2 \mathrm{~A}}$ receptors.

\section{Discussion}

In this study, we show robust serotonergic inhibition of L6 pyramidal neurons and their output to L5 interneurons. This suppression of $\mathrm{L6}$ activity by $5-\mathrm{HT}$ is driven by the combined effects of 5- $\mathrm{HT}_{1 \mathrm{~A}}$ and $5-\mathrm{HT}_{2 \mathrm{~A}}$ receptors. Using transgenic mice and optogenetic techniques, we illustrate a functional link between L6 pyramidal neurons and L5 interneurons potentially important to performance on attention tasks. Light stimulation in L6 strongly excited L5 interneurons. This excitatory connection was inhibited by $5-\mathrm{HT}$ and was restored in the presence of $5-\mathrm{HT}_{1 \mathrm{~A}}$ and
A

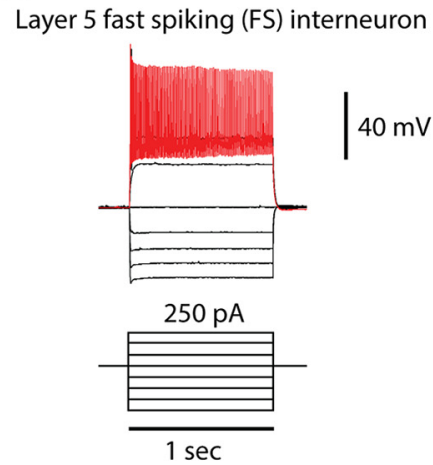

D

Layer 5 non-fast spiking (nFS) interneuron
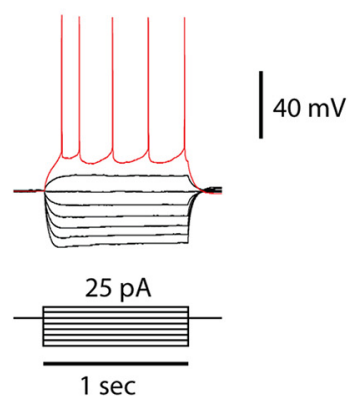

B

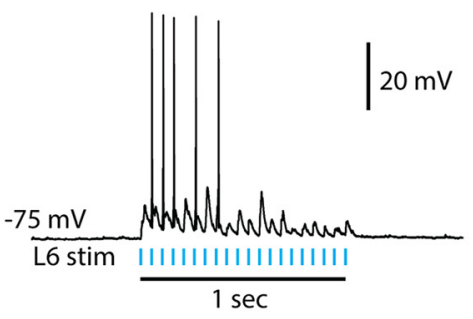

E

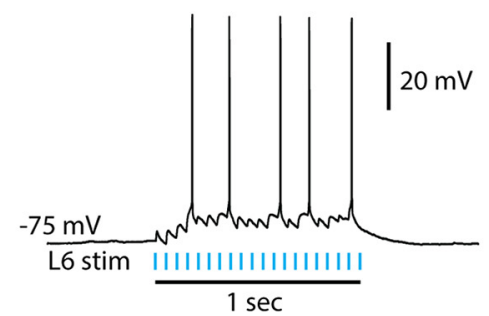

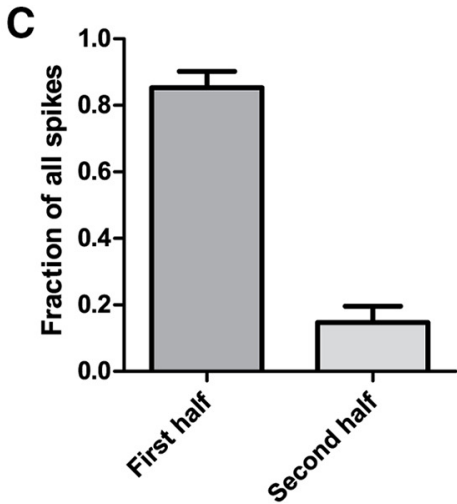

$\mathbf{F}$

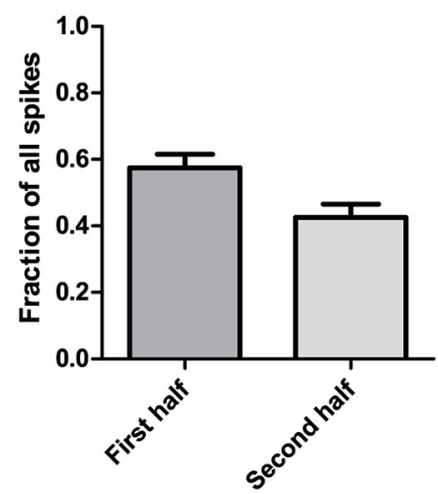

Figure 5. Two distinct groups of interneurons are found in L5 and are activated by light stimulation of L6 pyramidal neurons. $\boldsymbol{A}$, FS interneurons of L5 characterized by injection of current steps. $\boldsymbol{B}$, Representative trace of an L5 FS interneuron activated by L6. Note the rapidly depressing response to L6 activation. $\boldsymbol{C}$, Activation of FS interneurons by L6 elicited action potential firing primarily during the initial phase of activation that rapidly depressed over the duration of the stimulation (number of elicited action potentials in first half of stimulation vs. second half: $t_{9}=7.2, p<0.0001$, unpaired $t$ test). $\boldsymbol{D}, \mathrm{nFS}$ interneurons of L5 characterized by injection of current steps. $\boldsymbol{E}$, Representative trace of a L5 nFS interneuron activated by L6, demonstrating a more regular firing pattern. $\boldsymbol{F}$, L5 nFS interneurons were activated by $L 6$ and fired in a regular pattern over the course of the stimulation (number of elicited action potentials in first half of stimulation vs. second half: $t_{7}=1.9, p=0.1$, unpaired $t$ test). 
A

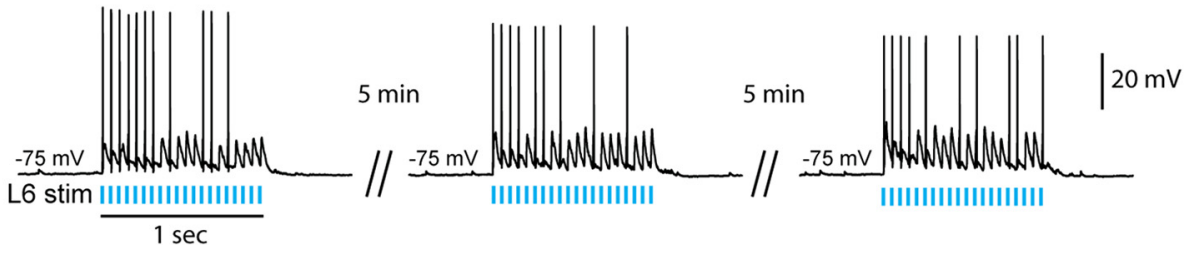

B

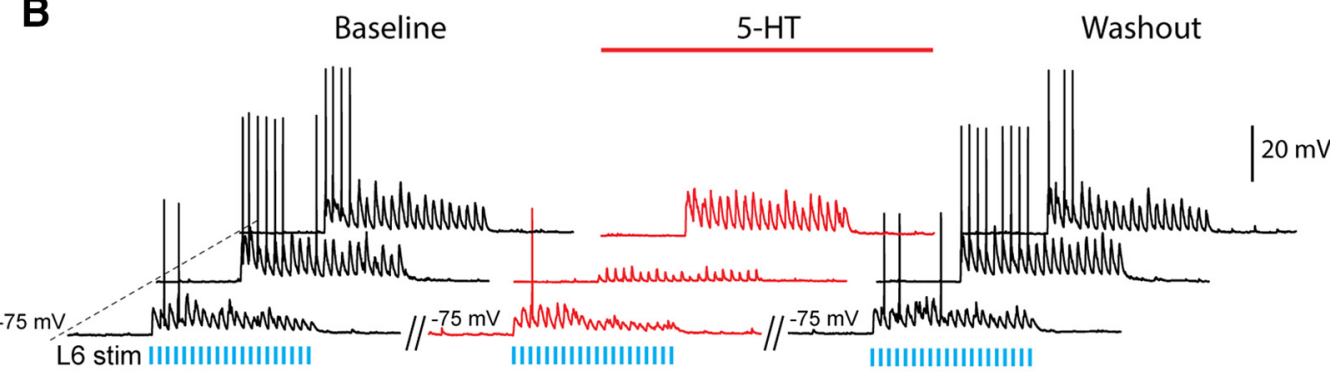

C

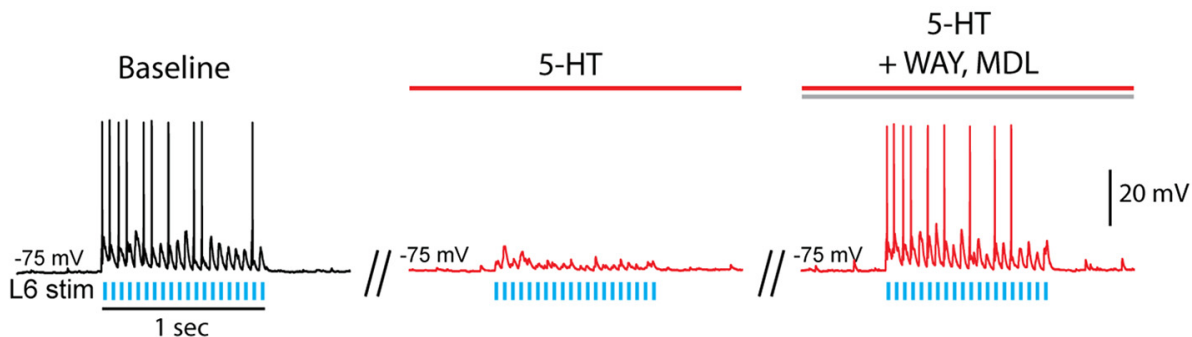

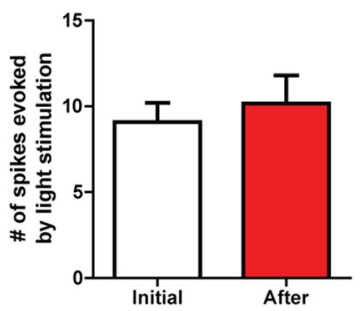
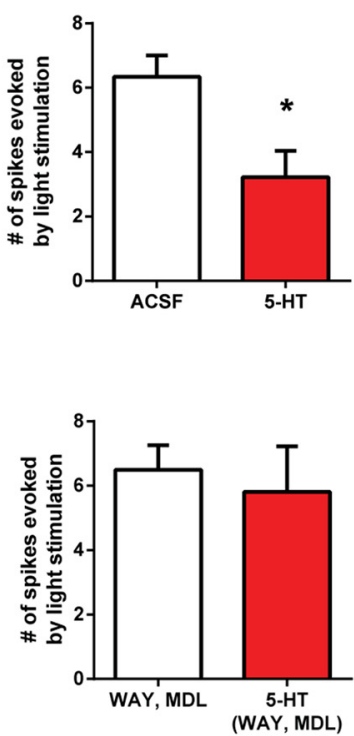

Figure 6. L6 activation of L5 interneurons in medial prefrontal cortex is stable over time but suppressed by 5 -HT. $\boldsymbol{A}$, Excitatory effects on L5 interneurons by optogenetic activation of L6 were stable and repeatable over time. Shown here are the postsynaptic responses in a L5 interneuron to L6 light-stimulation repeated over $15 \mathrm{~min}$. The number of spikes elicited initially and upon repetition in L5 interneurons is plotted on the bar graph at the right (mean \pm SEM). There was no significant difference $\left(t_{11}=0.8, p=0.4\right.$, paired $t$ test), showing that the postsynaptic effect in L5 interneurons does not decrease over time under baseline conditions. $\boldsymbol{B}$, L6 activation of L5 FS interneurons was significantly suppressed by $5-\mathrm{HT}\left(t_{8}=3.8, p=0.005\right.$, paired $t$ test, $n=9$ ). Shown here are repeated recordings (baseline, $5-\mathrm{HT}$, washout) from three different L5 interneurons. The number of spikes elicited at baseline and in the presence of 5-HT in L5 interneurons are illustrated in the bar graph on the right (mean \pm SEM). $\boldsymbol{C}$, Antagonists of serotonergic $5-\mathrm{HT}_{1 \mathrm{~A}}$ and $5-\mathrm{HT}_{2 \mathrm{~A}}$ receptors blocked the inhibitory effects of $5-\mathrm{HT}$ on $\mathrm{L} 6$ activation of L5 interneurons $\left(t_{15}=0.9, p=0.4\right.$, paired $t$ test, $\left.n=16\right)$. Shown here is one representative L5 interneuron excited by L6 stimulation, which is suppressed by 5-HT applied alone, and no longer suppressed by 5-HT in the presence of WAY100635 and MDL100907. The results are plotted on the bar graph at the right (mean \pm SEM).

$5-\mathrm{HT}_{2 \mathrm{~A}}$ antagonists. Taken together, these results suggest that $5-\mathrm{HT}_{1 \mathrm{~A}}$ and $5-\mathrm{HT}_{2 \mathrm{~A}}$ receptors mediate a strong inhibitory drive in L6 that can suppress its local activation of cortical targets in L5, which others have shown to be critical to attention (Kim et al., 2016).

\section{Prefrontal L6 pyramidal neurons excite a diverse group of interneurons in L5}

We found that L6 pyramidal neurons excited both FS and $\mathrm{nFS}$ interneurons in L5 of mPFC. These groups of interneurons likely represent the parvalbumin-expressing (PV) and somatostatin-expressing (SOM) groups of interneurons, which together form the majority of interneurons in cortical L5 (Kawaguchi and Kubota, 1997; Rudy et al., 2011). Both perisomatic PV and dendrite-targeting SOM interneurons are strong mediators of activity on downstream cortical pyramidal output (Kawaguchi and Kubota, 1997; Glickfeld et al., 2009; Kvitsiani et al., 2013; Hangya et al., 2014), with mPFC PV interneuron activity particularly important to normal performance on attention tasks (Kim et al., 2016). Our finding of a functional connection between L6 and L5 interneurons suggests a means by which L6 could influence mPFC cortical gain modulation, as has been observed in primary sensory cortices (Olsen et al., 2012; Bortone et al., 2014). These findings are in agreement with previous work in primary sensory cortex that examined anatomical and functional connections within the cortical column (Zhang and Deschênes, 1997; Thomson et al., 2002; Mercer et al., 2005; Watts and Thomson, 2005; West et al., 2006; Kim et al., 2014). This research suggests that activation of L6 is a driver of intracortical inhibition leading to a widespread suppression of cortical targets, observed in vivo in visual cortex (Beierlein et al., 2003; Olsen et al., 2012; Bortone et al., 2014). The L6 excitation of $n F S$ in addition to FS interneurons in mPFC suggests additional complexity in association cortex. Our data show for the first time that excitatory output from L6 can drive interneuron activity in $\mathrm{L} 5$ in $\mathrm{mPFC}$, a region critical for attention and other executive functions. 


\section{Serotonergic inhibition of this L6-to-L5 intracortical circuit}

We found that $5-\mathrm{HT}$, via stimulation of $5-\mathrm{HT}_{1 \mathrm{~A}}$ and $5-\mathrm{HT}_{2 \mathrm{~A}}$ receptors, inhibited L6 pyramidal neurons and their activation of L5 interneurons. These two receptors show substantial colocalization in L6 pyramidal neurons in mPFC of mouse (Table 3 in Amargós-Bosch et al., 2004), yet typically appear to exert opposing electrophysiological effects in other cortical layers (Benekareddy et al., 2010; Avesar and Gulledge, 2012; Stephens et al., 2014). Whereas $5-\mathrm{HT}_{1 \mathrm{~A}}$ receptors are known inhibitory receptors acting via Kir3 channels (Goodfellow et al., 2014; Johnston et al., 2014), 5- $\mathrm{HT}_{2 \mathrm{~A}}$ receptors act through a less well-characterized set of channels to excite certain populations of neurons, including a subset of L5 pyramidal neurons in mPFC (Willins et al., 1999; Benekareddy et al., 2010; Weber and Andrade, 2010; Avesar and Gulledge, 2012). Direct inhibition of $\mathrm{L} 6$ pyramidal neurons by $5-\mathrm{HT}_{2 \mathrm{~A}}$ receptors could arise from a number of possible mechanisms, including the suppression of sodium channels (Carr et al., 2002) or via 5- $\mathrm{HT}_{2 \mathrm{~A}}$ heteromers with inhibitory signaling (González-Maeso et al., 2007; Moreno et al., 2011; Viñals et al., 2015). Pyramidal neurons in L6 also have prominent afterhyperpolarizations (Proulx et al., 2015), known to affect excitability. Accordingly, the $\mathrm{G} \alpha_{\mathrm{q}}$-coupled 5- $\mathrm{HT}_{2 \mathrm{~A}}$ receptors may affect the excitability of these neurons by modulating channels contributing to different phases of the afterhyperpolarization (Gulledge and Stuart, 2005; Gulledge et al., 2009; but see also: Villalobos et al., 2005; Villalobos et al., 2011). Complex and carefully controlled future work will be necessary to identify the mechanisms underlying the $5-\mathrm{HT}_{2 \mathrm{~A}}$ receptor-mediated inhibition of $\mathrm{L} 6$ pyramidal neuron excitability.

In investigating FS and $\mathrm{nFS}$ interneurons in L5, we found that the majority of these cells did not respond strongly to $5-\mathrm{HT}$. A minority showed electrophysiological responses (FS, 4/13; nFS, 2/16), predominantly inward currents (less than $-20 \mathrm{pA}$ ) that were insufficient to elicit spiking. These proportions are consistent with the literature on the expression of 5-HT receptors only in a small proportion of L5 interneurons (Abi-Saab et al., 1999; Santana et al., 2004; Rudy et al., 2011; Celada et al., 2013). Our findings were not significantly altered by the inclusion or exclusion of these neurons. Control experiments with GABA-A and GABA-B blockers suggest that 5-HT receptors on interneurons are not significantly involved in the 5-HT suppression of L6 pyramidal neurons. Taken together, our data support the hypothesis that the combined activation of both $5-\mathrm{HT}_{1 \mathrm{~A}}$ and $5-\mathrm{HT}_{2 \mathrm{~A}}$ receptors can inhibit neuronal excitability in $\mathrm{L} 6$ neurons of prefrontal cortex. However, further pharmacological work is required to examine the specific downstream mechanisms underlying this inhibition of L6 pyramidal neurons. Furthermore, additional investigations into the consequences of serotonergic inhibition of L6 on local network dynamics will provide more insight into the nature of these important associative circuits and how they control attention.

\section{Serotonin, prefrontal attention circuitry, and attention deficits in psychiatric illness}

Prefrontal attention circuitry is complex, and attentional performance can be perturbed by extremes of mPFC activity in either direction (Pezze et al., 2014). Serotonin shapes and biases attention in humans and rodents, with low levels of 5-HT enhancing attention (Schmitt et al., 2000; Gallagher et al., 2003; Booij et al., 2005) and higher levels of 5-HT disrupting attention (Riedel et al., 2005; Wingen et al., 2007; Watson et al., 2015) through 5- $\mathrm{HT}_{1 \mathrm{~A}}$ and 5- $\mathrm{HT}_{2 \mathrm{~A}}$ receptors (Wingen et al., 2007). Stress is well known to raise prefrontal serotonin levels (Adell et al., 1997; Fujino et al., 2002; Bland et al., 2004), and similar behavioral manipulations disrupt attention (Minor et al., 1984; Sänger et al., 2014). Intriguingly, elevation of intracortical 5-HT has been strongly associated with deficits in attention (Puumala and Sirviö, 1998) and increases in impulsivity (Dalley et al., 2002). Specific activation of $5-\mathrm{HT}_{1 \mathrm{~A}}$ and $5-\mathrm{HT}_{2 \mathrm{~A}}$ receptors results in similar attention deficits (Carli and Samanin, 2000; Koskinen et al., 2000). Conversely, infusion of antagonists to $5-\mathrm{HT}_{2 \mathrm{~A}}$ receptors into mPFC improved performance on attention tasks in rodents and reduced impulsivity (Passetti et al., 2003; Winstanley et al., 2003).

Although manipulation of 5-HT receptors specifically in mPFC can manipulate attention, certain key experiments (e.g., attention under stress or in models of dysregulated $5-\mathrm{HT}$ signaling) remain to be done. Based on our findings, rising levels of cortical 5-HT may increase cortical noise owing to suppression of L6-mediated cortical inhibition. Increasing the signal-to-noise ratio is strongly correlated with attentional focus (Briggs et al., 2013; Pratte et al., 2013), whereas deficits can arise from increasing cortical noise in prefrontal cortex (Pezze et al., 2014), Similarly, disruptions to normal excitation of L6 neurons of mPFC can lead to attention deficits in rodents, although previous studies have focused on cholinergic stimulation of L6 (Bailey et al., 2010; Guillem et al., 2011). Our study is the first to demonstrate the strong inhibitory modulation exerted on L6 by $5-\mathrm{HT}$ and the resultant decrease in its ability to stimulate interneuron activity in L5. Taken together, this evidence shows that L6 of mPFC is a candidate locus of action for the modulatory effects of $5-\mathrm{HT}$ on attention. Based on recent work in nonhuman primates (Watson et al., 2015), it is tempting to speculate that 5-HT levels in deep mPFC may modulate the balance between social vigilance and attentional task performance, a phenomenon that is impaired in several neuropsychiatric illnesses.

\section{References}

Abi-Saab WM, Bubser M, Roth RH, Deutch AY (1999) 5-HT2 receptor regulation of extracellular GABA levels in the prefrontal cortex. Neuropsychopharmacology 20:92-96. CrossRef Medline

Adell A, Casanovas JM, Artigas F (1997) Comparative study in the rat of the actions of different types of stress on the release of 5-HT in raphe nuclei and forebrain areas. Neuropharmacology 36:735741. Medline

Alitto HJ, Usrey WM (2003) Corticothalamic feedback and sensory processing. Curr Opin Neurobiol 13:440-445. Medline 
Amargós-Bosch M, Bortolozzi A, Puig MV, Serrats J, Adell A, Celada $P$, Toth M, Mengod G, Artigas F (2004) Co-expression and in vivo interaction of serotonin1 $A$ and serotonin2A receptors in pyramidal neurons of prefrontal cortex. Cereb Cortex 14:281-299. Medline

Ascoli GA, et al. (2008) Petilla terminology: nomenclature of features of GABAergic interneurons of the cerebral cortex. Nat Rev Neurosci 9:557-568. CrossRef Medline

Avesar D, Gulledge AT (2012) Selective serotonergic excitation of callosal projection neurons. Front Neural Circuits 6:12CrossRef Medline

Bailey CDC, de Biasi M, Fletcher PJ, Lambe EK (2010) The nicotinic acetylcholine receptor alpha5 subunit plays a key role in attention circuitry and accuracy. J Neurosci 30:9241-9252. CrossRef

Beierlein M, Gibson JR, Connors BW (2003) Two dynamically distinct inhibitory networks in layer 4 of the neocortex. J Neurophysiol 90:2987-3000. CrossRef Medline

Benekareddy M, Goodfellow NM, Lambe EK, Vaidya VA (2010) Enhanced function of prefrontal serotonin 5-HT(2) receptors in a rat model of psychiatric vulnerability. J Neurosci 30:12138-12150. CrossRef Medline

Bland ST, Twining C, Schmid MJ, Der-Avakian A, Watkins LR, Maier SF (2004) Stress potentiation of morphine-induced dopamine efflux in the nucleus accumbens shell is dependent upon stressor uncontrollability and is mediated by the dorsal raphe nucleus. Neuroscience 126:705-715. CrossRef Medline

Booij L, van der Does AJW, Haffmans PMJ, Riedel WJ, Fekkes D, Blom MJB (2005) The effects of high-dose and low-dose tryptophan depletion on mood and cognitive functions of remitted depressed patients. J Psychopharmacol (Oxford) 19:267-275. CrossRef

Bortone DS, Olsen SR, Scanziani M (2014) Translaminar inhibitory cells recruited by layer 6 corticothalamic neurons suppress visual cortex. Neuron 82:474-485. CrossRef Medline

Briggs F, Mangun GR, Usrey WM (2013) Attention enhances synaptic efficacy and the signal-to-noise ratio in neural circuits. Nature 499:476-480. CrossRef Medline

Carli M, Samanin R (2000) The 5- $\mathrm{HT}(1 \mathrm{~A})$ receptor agonist 8-OHDPAT reduces rats' accuracy of attentional performance and enhances impulsive responding in a five-choice serial reaction time task: role of presynaptic 5-HT(1A) receptors. Psychopharmacology (Berlin) 149:259-268. CrossRef

Carr DB, Cooper DC, Ulrich SL, Spruston N, Surmeier DJ (2002) Serotonin receptor activation inhibits sodium current and dendritic excitability in prefrontal cortex via a protein kinase C-dependent mechanism. J Neurosci 22:6846-6855.

Celada P, Puig MV, Artigas F (2013) Serotonin modulation of cortical neurons and networks. Front Integr Neurosci 7:25CrossRef Medline

Chalmers DT, Watson SJ (1991) Comparative anatomical distribution of $5-\mathrm{HT} 1 \mathrm{~A}$ receptor mRNA and $5-\mathrm{HT} 1 \mathrm{~A}$ binding in rat brain-a combined in situ hybridisation/in vitro receptor autoradiographic study. Brain Res 561:51-60. Medline

Chugani DC (2002) Role of altered brain serotonin mechanisms in autism. Mol Psychiatr 7 Suppl 2:S16-S17. CrossRef Medline

Cornea-Hébert V, Riad M, Wu C, Singh SK, Descarries L (1999) Cellular and subcellular distribution of the serotonin 5-HT2A receptor in the central nervous system of adult rat. J Comp Neurol 409:187-209. Medline

Dalley JW, Theobald DE, Eagle DM, Passetti F, Robbins TW (2002) Deficits in impulse control associated with tonically-elevated serotonergic function in rat prefrontal cortex. Neuropsychopharmacology 26:716-728. CrossRef Medline

de Almeida J, Mengod G (2007) Quantitative analysis of glutamatergic and GABAergic neurons expressing $5-\mathrm{HT}(2 \mathrm{~A})$ receptors in human and monkey prefrontal cortex. J Neurochem 103:475-486. CrossRef Medline

de Almeida J, Mengod G (2008) Serotonin 1A receptors in human and monkey prefrontal cortex are mainly expressed in pyramidal neurons and in a GABAergic interneuron subpopulation: implica- tions for schizophrenia and its treatment. J Neurochem 107:488496. CrossRef Medline

Doyle JP, Dougherty JD, Heiman M, Schmidt EF, Stevens TR, Ma G, Bupp S, Shrestha P, Shah RD, Doughty ML, et al. (2008) Application of a translational profiling approach for the comparative analysis of CNS cell types. Cell 135:749-762. CrossRef

Ernst OP, Murcia PAS, Daldrop P, Tsunoda SP, Kateriya S, Hegemann $P$ (2008) Photoactivation of channelrhodopsin. J Biol Chem 283:1637-1643. CrossRef Medline

Feldmeyer D, Roth A, Sakmann B (2005) Monosynaptic connections between pairs of spiny stellate cells in layer 4 and pyramidal cells in layer 5A indicate that lemniscal and paralemniscal afferent pathways converge in the infragranular somatosensory cortex. $J$ Neurosci 25:3423-3431. CrossRef Medline

Ferland RJ, Cherry TJ, Preware PO, Morrisey EE, Walsh CA (2003) Characterization of Foxp2 and Foxp1 mRNA and protein in the developing and mature brain. J Comp Neurol 460:266-279. CrossRef Medline

Frick A, Feldmeyer D, Helmstaedter M, Sakmann B (2008) Monosynaptic connections between pairs of L5A pyramidal neurons in columns of juvenile rat somatosensory cortex. Cereb Cortex 18: 397-406. CrossRef Medline

Fujino K, Yoshitake T, Inoue O, Ibii N, Kehr J, Ishida J, Nohta H, Yamaguchi M (2002) Increased serotonin release in mice frontal cortex and hippocampus induced by acute physiological stressors. Neurosci Lett 320:91-95. Medline

Gallagher P, Massey AE, Young AH, McAllister-Williams RH (2003) Effects of acute tryptophan depletion on executive function in healthy male volunteers. BMC Psychiatr 3:10CrossRef Medline

Glickfeld LL, Roberts JD, Somogyi P, Scanziani M (2009) Interneurons hyperpolarize pyramidal cells along their entire somatodendritic axis. Nat Neurosci 12:21-23. CrossRef Medline

Gong S, Doughty M, Harbaugh CR, Cummins A, Cummins E, Hatten ME, Heintz N, Gerfen CR (2007) Targeting Cre recombinase to specific neuron populations with bacterial artificial chromosome constructs. J Neurosci 27:9817-9823. CrossRef

Gong S, Zheng C, Doughty ML, Losos K, Didkoversusky N, Schambra UB, Nowak NJ, Alex Joyner A, Joyner R, Leblanc G, Hatten ME, Heintz N (2003) A gene expression atlas of the central nervous system based on bacterial artificial chromosomes. Nature 425: 917-925. CrossRef

González-Maeso J, Weisstaub NV, Zhou M, Chan P, Ivic L, Ang R, Lira A, Bradley-Moore M, Ge Y, Zhou Q, Sealfon SC, Gingrich JA (2007) Hallucinogens recruit specific cortical 5-HT(2A) receptormediated signaling pathways to affect behavior. Neuron 53:439452. CrossRef Medline

Goodfellow NM, Sargin D, Ansorge MS, Gingrich JA, Lambe EK (2014) Mice with compromised 5-HTT function lack phosphotyrosine-mediated inhibitory control over prefrontal 5-HT responses. J Neurosci 34:6107-6111. CrossRef Medline

Granon S, Hardouin J, Courtièr A, Poucet B (1998) Evidence for the involvement of the rat prefrontal cortex in sustained attention. $Q \mathrm{~J}$ Exp Psychol B 51:219-233. CrossRef Medline

Guillem K, Bloem B, Poorthuis RB, Loos M, Smit AB, Maskos U, Spijker S, Mansvelder HD (2011) Nicotinic acetylcholine receptor $\beta 2$ subunits in the medial prefrontal cortex control attention. Science 333:888-891. CrossRef Medline

Guillery RW, Sherman SM (2002) The thalamus as a monitor of motor outputs. Philos Trans R Soc Lond Ser B Biol Sci 357:1809-1821. CrossRef Medline

Gulledge AT, Stuart GJ (2005) Cholinergic inhibition of neocortical pyramidal neurons. J Neurophysiol 97:2215-2229. CrossRef Medline

Gulledge AT, Bucci DJ, Zhang SS, Matsui M, Yeh HH (2009) M1 Receptors mediate cholinergic modulation of excitability in neocortical pyramidal neurons. J Neurosci 29:9888-9902. CrossRef Medline

Hangya B, Pi H, Kvitsiani D, Ranade SP, Kepecs A (2014) From circuit motifs to computations: mapping the behavioral repertoire 
of cortical interneurons. Curr Opin Neurobiol 26:117-124. CrossRef Medline

Heiman M, Kulicke R, Fenster RJ, Greengard P, Heintz N (2014) Cell type-specific mRNA purification by translating ribosome affinity purification (TRAP). Nat Protoc 9:1282-1291. CrossRef Medline

Heiman M, Schaefer A, Gong S, Peterson JD, Day M, Ramsey KE, Suárez-Fariñas M, Schwarz C, Stephan DA, Surmeier DJ, et al. (2008) A translational profiling approach for the molecular characterization of CNS cell types. Cell 135:738-748. CrossRef

Jans LAW, Riedel WJ, Markus CR, Blokl A, Blokland A (2007) Serotonergic vulnerability and depression: assumptions, experimental evidence and implications. Mol Psychiatry 12:522-543. CrossRef

Johnston A, McBain CJ, Fisahn A (2014) 5-Hydroxytryptamine1A receptor-activation hyperpolarizes pyramidal cells and suppresses hippocampal gamma oscillations via Kir3 channel activation. J Physiol (Lond) 592:4187-4199. CrossRef

Kane MJ, Angoa-Peréz M, Briggs DI, Sykes CE, Francescutti DM, Rosenberg DR, Kuhn DM (2012) Mice genetically depleted of brain serotonin display social impairments, communication deficits and repetitive behaviors: possible relevance to autism. PLoS ONE 7:e48975CrossRef Medline

Kassam SM, Herman PM, Goodfellow NM, Alves NC, Lambe EK (2008) Developmental excitation of corticothalamic neurons by nicotinic acetylcholine receptors. J Neurosci 28:8756-8764. CrossRef Medline

Kawaguchi Y, Kubota Y (1997) GABAergic cell subtypes and their synaptic connections in rat frontal cortex. Cereb Cortex 7:476486.

Kim H, Ährlund-Richter S, Wang X, Deisseroth K, Carlén M (2016) Prefrontal parvalbumin neurons in control of attention. Cell 164: 208-218. CrossRef Medline

Kim J, Matney CJ, Blankenship A, Hestrin S, Brown SP (2014) Layer 6 corticothalamic neurons activate a cortical output layer, layer 5 a. J Neurosci 34:9656-9664. CrossRef Medline

Knudsen E (2007) Fundamental components of attention. Annu Rev Neurosci 30:57-78. CrossRef Medline

Koskinen T, Ruotsalainen S, Puumala T, Lappalainen R, Koivisto E, Männistö PT, Sirviö J (2000) Activation of 5-HT2A receptors impairs response control of rats in a five-choice serial reaction time task. Neuropharmacology 39:471-481. Medline

Kurrasch-Orbaugh DM, Parrish JC, Watts VJ, Nichols DE (2003) A complex signaling cascade links the serotonin2A receptor to phospholipase A2 activation: the involvement of MAP kinases. J Neurochem 86:980-991. Medline

Kvitsiani D, Ranade S, Hangya B, Taniguchi H, Huang JZ, Kepecs A (2013) Distinct behavioural and network correlates of two interneuron types in prefrontal cortex. Nature 498:363-366. CrossRef Medline

Lambe EK, Aghajanian GK (2001) The role of Kv1.2-containing potassium channels in serotonin-induced glutamate release from thalamocortical terminals in rat frontal cortex. J Neurosci 21:99559963. Medline

Linley SB, Hoover WB, Vertes RP (2013) Pattern of distribution of serotonergic fibers to the orbitomedial and insular cortex in the rat. $\mathrm{J}$ Chem Neuroanat 48-49:29-45. CrossRef Medline

Livak KJ, Schmittgen TD (2001) Analysis of relative gene expression data using real-time quantitative PCR and the 2(-Delta Delta $\mathrm{C}(\mathrm{T})$ ) Method. Methods 25:402-408. CrossRef Medline

Luck S, Gold J (2008) The construct of attention in schizophrenia. Biol Psychiatry 64:34-39. CrossRef Medline

Markram H, Lübke J, Frotscher M, Roth A, Sakmann B (1997) Physiology and anatomy of synaptic connections between thick tufted pyramidal neurones in the developing rat neocortex. J Physiol (London) 500: 409-440. CrossRef

Markram H, Toledo-Rodriguez M, Wang Y, Gupta A, Silberberg G, Wu C (2004) Interneurons of the neocortical inhibitory system. Nat Rev Neurosci 5:793-807. CrossRef Medline

Marvel CL, Paradiso S (2004) Cognitive and neurological impairment in mood disorders. Psychiatr Clin N Am 27:19-36. vii-viii. CrossRef Medline
Mease RA, Krieger P, A, Groh A, Groh E (2014) Cortical control of adaptation and sensory relay mode in the thalamus. Proc Natl Acad Sci U S A 111:6798-6803. CrossRef Medline

Mengod G, Palacios JM, Cortés R (2015) Cartography of 5-HT1A and 5-HT2A receptor subtypes in prefrontal cortex and its projections. ACS Chem Neurosci 6:1089-1098. CrossRef Medline

Mercer A, West DC, Morris OT, Kirchhecker S, Kerkhoff JE, Thomson AM (2005) Excitatory connections made by presynaptic corticocortical pyramidal cells in layer 6 of the neocortex. Cereb Cortex 15:1485-1496. CrossRef Medline

Miller EK, Cohen JD (2001) An integrative theory of prefrontal cortex function. Annu Rev Neurosci 24:167-202. CrossRef Medline

Miner LA, Ostr M, Ostrander M, er, Sarter M (1997) Effects of ibotenic acid-induced loss of neurons in the medial prefrontal cortex of rats on behavioral vigilance: evidence for executive dysfunction. $J$ Psychopharmacol (Oxford) 11:169-178. CrossRef

Minor TR, Jackson RL, Maier SF (1984) Effects of task-irrelevant cues and reinforcement delay on choice-escape learning following inescapable shock: evidence for a deficit in selective attention. J Exp Psychol Anim Behav Process 10:543-556. Medline

Moreno JL, Holloway T, Albizu L, Sealfon SC, González-Maeso J (2011) Metabotropic glutamate mGlu2 receptor is necessary for the pharmacological and behavioral effects induced by hallucinogenic 5-HT2A receptor agonists. Neurosci Lett 493:76-79. CrossRef Medline

Muir JL, Everitt BJ, Robbins TW (1996) The cerebral cortex of the rat and visual attentional function: dissociable effects of mediofrontal, cingulate, anterior dorsolateral, and parietal cortex lesions on a five-choice serial reaction time task. Cereb Cortex 6:470-481. Medline

Murrough JW, lacoviello B, Alex Neumeister A, Neumeister E, Charney DS, losifescu DV (2011) Cognitive dysfunction in depression: neurocircuitry and new therapeutic strategies. Neurobiol Learning Memory 96:553-563. CrossRef

Muzerelle A, Scotto-Lomassese S, Bernard JF, Soiza-Reilly M, Gaspar $\mathrm{P}(2016)$ Conditional anterograde tracing reveals distinct targeting of individual serotonin cell groups (B5-B9) to the forebrain and brainstem. Brain Struct Funct 221:535-561. CrossRef Medline

Olsen SR, Bortone DS, Adesnik H, Scanziani M (2012) Gain control by layer six in cortical circuits of vision. Nature 483:47-52. CrossRef Medline

Oranje B, Jensen K, Wienberg M, Glenthøj BY (2008) Divergent effects of increased serotonergic activity on psychophysiological parameters of human attention. Int $\mathrm{J}$ Neuropsychopharmacol 11: 453-463. CrossRef Medline

Parikh V, Kozak R, Martinez V, Sarter M (2007) Prefrontal acetylcholine release controls cue detection on multiple timescales. Neuron 56:141-154. CrossRef Medline

Passetti F, Dalley JW, Robbins TW (2003) Double dissociation of serotonergic and dopaminergic mechanisms on attentional performance using a rodent five-choice reaction time task. Psychopharmacology (Berlin) 165:136-145. CrossRef Medline

Pezze M, McGarrity S, Mason R, Fone KC, Bast T (2014) Too little and too much: hypoactivation and disinhibition of medial prefrontal cortex cause attentional deficits. J Neurosci 34:7931-7946. CrossRef Medline

Pompeiano M, Palacios JM, Mengod G (1992) Distribution and cellular localization of mRNA coding for 5-HT1A receptor in the rat brain: correlation with receptor binding. J Neurosci 12:440-453. Medline

Pompeiano M, Palacios JM, Mengod G (1994) Distribution of the serotonin 5-HT2 receptor family mRNAs: comparison between 5-HT2A and 5-HT2C receptors. Brain Res Molecular Brain Res 23:163-178. Medline

Pratte MS, Ling S, Swisher JD, Tong F (2013) How attention extracts objects from noise. J Neurophysiol 110:1346-1356. CrossRef Medline

Proulx É, Fraser P, McLaurin J, Lambe EK (2015) Impaired cholinergic excitation of prefrontal attention circuitry in the TgCRND8 
model of Alzheimer's disease. J Neurosci 35:12779-12791. CrossRef Medline

Puumala T, Sirviö J (1998) Changes in activities of dopamine and serotonin systems in the frontal cortex underlie poor choice accuracy and impulsivity of rats in an attention task. Neuroscience 83:489-499. Medline

Riedel WJ, Eikmans K, Heldens A, Schmitt JAJ (2005) Specific serotonergic reuptake inhibition impairs vigilance performance acutely and after subchronic treatment. J Psychopharmacol (Oxford) 19:12-20. CrossRef

Rudy B, Fishell G, Lee S, Hjerling-Leffler J (2011) Three groups of interneurons account for nearly $100 \%$ of neocortical GABAergic neurons. Dev Neurobiol 71:45-61. CrossRef Medline

Sänger J, Bechtold L, Schoofs D, Blaszkewicz M, Wascher E (2014) The influence of acute stress on attention mechanisms and its electrophysiological correlates. Front Behav Neurosci 8:353CrossRef Medline

Santana N, Bortolozzi A, Serrats J, Mengod G, Artigas F (2004) Expression of serotonin1A and serotonin2A receptors in pyramidal and GABAergic neurons of the rat prefrontal cortex. Cereb Cortex 14:1100-1109. CrossRef Medline

Schmidt EF, Warner-Schmidt JL, Otopalik BG, Pickett SB, Greengard P, Heintz N (2012) Identification of the cortical neurons that mediate antidepressant responses. Cell 149:1152-1163. CrossRef Medline

Schmitt JA, Jorissen BL, Sobczak S, van Boxtel MP, Hogervorst E, Deutz NE, Riedel WJ (2000) Tryptophan depletion impairs memory consolidation but improves focussed attention in healthy young volunteers. J Psychopharmacol (Oxford) 14:21-29. CrossRef

Sherman SM (2007) The thalamus is more than just a relay. Curr Opin Neurobiol 17:417-422. CrossRef Medline

Stephens EK, Avesar D, Gulledge AT (2014) Activity-dependent serotonergic excitation of callosal projection neurons in the mouse prefrontal cortex. Front Neural Circuits 8:97CrossRef Medline

Thomson A (2010) Neocortical layer 6, a review. Front Neuroanat 4:13 CrossRef Medline

Thomson AM, Bannister AP, Mercer A, Morris OT (2002) Target and temporal pattern selection at neocortical synapses. Philos Trans $\mathrm{R}$ Soc Lond Ser B Biol Sci 357:1781-1791. CrossRef Medline

Tian MK, Bailey CDC, Lambe EK (2014) Cholinergic excitation in mouse primary versus associative cortex: region-specific magnitude and receptor balance. Eur J Neurosci 40:2608-2618. CrossRef

Vélez-Fort M, Margrie TW (2012) Cortical circuits: layer 6 is a gain changer. Curr Biol 22:R411-R413. CrossRef Medline

Villalobos C, Beique J, Gingrich JA, Andrade R (2005) Serotonergic regulation of calcium-activated potassium currents in rodent prefrontal cortex. Eur J Neurosci 22:1120-1126. CrossRef Medline

Villalobos C, Foehring RC, Lee JC, Andrade R (2011) Essential role for phosphatidylinositol 4,5-bisphosphate in the expression, regulation, and gating of the slow afterhyperpolarization current in the cerebral cortex. J Neurosci 31:18303-18312.
Viñals X, Moreno E, Lanfumey L, Cordomí A, Pastor A, La Torre de R, Gasperini P, Navarro G, Howell LA, Pardo L, Lluís C, Canela El, McCormick PJ, Maldonado R, Robledo P (2015) Cognitive impairment induced by Delta9-tetrahydrocannabinol occurs through heteromers between cannabinoid $\mathrm{CB} 1$ and serotonin 5-HT2A receptors. PLoS Biol 13:e1002194CrossRef

Watson KK, Li D, Brent LJN, Horvath JE, Gonzalez-Martinez J, Lambides R, Robinson AG, Skene JHP, Platt ML (2015) Genetic influences on social attention in free-ranging rhesus macaques. Anim Behav 103:267-275. CrossRef

Watts J, Thomson AM (2005) Excitatory and inhibitory connections show selectivity in the neocortex. J Physiol (London) 562:89-97. CrossRef Medline

Weber ET, Andrade R (2010) Htr2a gene and 5-HT(2A) receptor expression in the cerebral cortex studied using genetically modified mice. Front Neurosci Advance online publication. doi:10.3389/ fnins.2010.00036.

Weisstaub NV, Zhou M, Lira A, Lambe E, González-Maeso J, Hornung J, Sibille E, Underwood M, Itohara S, Dauer WT, Ansorge MS, Morelli E, Mann JJ, Toth M, Aghajanian G, Sealfon SC, Hen R, Gingrich JA (2006) Cortical 5-HT2A receptor signaling modulates anxiety-like behaviors in mice. Science 313:536-540. CrossRef Medline

West DC, Mercer A, Kirchhecker S, Morris OT, Thomson AM (2006) Layer 6 cortico-thalamic pyramidal cells preferentially innervate interneurons and generate facilitating EPSPs. Cereb Cortex 16: 200-211. CrossRef Medline

Willins DL, Berry SA, Alsayegh L, Backstrom JR, Sanders-Bush E, Friedman L, Roth BL (1999) Clozapine and other 5-hydroxytryptamine-2A receptor antagonists alter the subcellular distribution of 5-hydroxytryptamine-2A receptors in vitro and in vivo. Neuroscience 91:599-606. Medline

Wilson MA, Molliver ME (1991) The organization of serotonergic projections to cerebral cortex in primates: regional distribution of axon terminals. Neuroscience 44:537-553. Medline

Wingen M, Kuypers KPC, Ramaekers JG (2007) The role of 5-HT1a and 5-HT2a receptors in attention and motor control: a mechanistic study in healthy volunteers. Psychopharmacology (Berlin) 190: 391-400. CrossRef

Winstanley CA, Chudasama Y, Dalley JW, Theobald DEH, Glennon JC, Robbins TW (2003) Intra-prefrontal 8-OH-DPAT and M100907 improve visuospatial attention and decrease impulsivity on the five-choice serial reaction time task in rats. Psychopharmacology (Berlin) 167:304-314.

Zhang Z, Arsenault D (2005) Gain modulation by serotonin in pyramidal neurones of the rat prefrontal cortex. J Physiol (London) 566:379-394. CrossRef Medline

Zhang Z, Deschênes M (1997) Intracortical axonal projections of lamina VI cells of the primary somatosensory cortex in the rat: a single-cell labeling study. J Neurosci 17:6365-6379. Medline

Zikopoulos B, Barbas H (2006) Prefrontal projections to the thalamic reticular nucleus form a unique circuit for attentional mechanisms. J Neurosci 26:7348-7361. CrossRef Medline 